\title{
January 1835
}

/28v/ Thursday $1^{\text {st }}$. Jan $^{y} .1835$.

This is one of the greatest Holidays in Paris - \& throughout France generally - the courses $\&$ schools are all closed $\&$ everyone seems determined to enjoy himself. This morning went to La Pitié. No examination \& nothing particular going on - went down to Hotel Dieu, but Breschet was there early this morning, \& had finished his visit, before my arrival. Entered Notre Dame, as I understood, Grand Mass was to be celebrated, but I was misinformed. I however heard the organ, which is only played on great occasions. It was magnificent - its rich tones accompanied by the voices of the choir, swelling thro' that magnificent Cathedral were truly sublime. It is impossible not to be stuck with this, on visiting the places of worship belonging to the R. Catholics. Went afterwards into the Ch: of $\mathbf{S}^{\mathbf{t}}$. Roch - but there was nothing more than usual. ${ }^{1}$ Today for the first time, since my arrival in Paris, I went to the reading room in the neighbourhood of the R. de la Paix - they take in, there, all the English \& American journals, Reviews \&c - whether Literary, Scientific or Medical. The terms of subscription are, I believe, $5 f^{f \cdot}$ a month -10 sous for a single visit. ${ }^{2}$ If it were not so far, I $\mathrm{w}^{\text {ld }}$. subscribe regularly to it, for the terms are very moderate. Took a $2 \mathrm{f}^{\mathrm{f}}$. dinner at the Palais Royal, \& afterwards went for the first time since coming to Paris to the Opera Francais. ${ }^{3}$ We intended to have gone into the Parterre, ${ }^{4}$ but this being full, we were obliged to go to the Amphitheatre Quatrieme, \& take one of the very back seats. The Opera played ${ }^{5}$ this Evening was "Robert $/ 29 \mathrm{r} /$ Le Diable", 6 an admirable production it is. The house is

\footnotetext{
${ }^{1}$ St. Roch did not hold a special Mass on New Year's Day.

${ }^{2}$ There were many reading rooms and libraries in Paris and the one most often visited by the diarist was that of the publishers Galignani at 18 rue Vivienne, which had a garden for the use of subscribers. Galignani's Reading Room was spacious and attractive, and provided the wide variety of newspapers and journals - in French and English - indicated by the diarist. It also contained maps and a collection of more than 20,000 books in several languages. It was well frequented by both the French and the English and the subscription was 10 sous a day, 4 francs a fortnight, 6 francs a month. (Galignani's new Paris guide, pp. 1, iii-iv.)

${ }^{3}$ The Opéra Français had already enjoyed a chequered career in terms of buildings, location and patrons and was officially titled the Académie Royale de Musique. The building visited by the diarist was opened as a temporary home in 1821 , and was architecturally imposing, with a high elevation and classical design with Doric and Corinthian columns and a dome embellished with the Muses and arabesques. It had seating for 1,937 . The Opéra was under the direction of the government, which paid more attention to its standards of performance than to its expenses. Indeed it enjoyed the advantage that all other theatres and places of entertainment paid taxes towards its maintenance. (Galignani's new Paris guide, pp. 545-9.)

${ }^{4}$ Parterre: the pit where the seats would have been a little more expensive -3 francs 12 sous - but offered a closer view than the amphitheatre ( 2 francs 10 sous) where they were obliged to go. (See additional sheet entitled 'Prices of Admission, Principal Performers, etc. at the different Theatres' inserted in the British Library copy of Galignani's new Paris guide, between pp. 540-1.)

5 Interesting that he uses "played", a translation of the French verb "jouer", rather than the correct English usage: "performed".

${ }^{6}$ This opera, a redemption story of the triumph of good over evil, was based on the comedy of Jean Nicholas Bouilly and Théophile Marion Dumersan, Robert le Diable, comédie en deux actes, mêlée de vaudevilles etc, Paris, 1813. Robert le Diable, the Duke of Normandy, had been a popular figure in the Middle Ages, celebrated in poetry and historical chronicles. The opera had been presented for the first time in the Theatre du Vaudeville on 31 December 1812, the year before it was first published. An English translation, by A. E. Scribe and G. Delavigne, appeared in 1832 (London, H. N. Millar [1832]). This, with ballet sequences "[a] grand pas de
} 


\section{January 1835}

much larger than Drury Lane, ${ }^{7} \&$ beautifully decorated - lighted with gas ${ }^{8} \&$ having an immense Chandelier in the middle, which may be elevated or depressed by means of pullies $\&$ chains. ${ }^{9}$ The entrance to the Opera is magnificent, \& the public gain admittance without any bustle or annoyance. ${ }^{10} \mathrm{~A}$ soldier standing at the entrance prevents more than two or three from being abreast, $\&$ all confusion is prevented by a railing enclosing a narrow space, thro' which the crowd must necessarily pass, to arrive at the open place, where the entrance fees are demanded. ${ }^{11}$ During the progress of the play, $\&$ between the Acts all noise is strictly prohibited, not a word is uttered - so entirely different from the uproarious noise, \&c often met with in the disgracefully conducted theatres of England. Into the Parterre, no females are admitted, \& I was particularly struck by the extremely small number of women in the whole house $-\&$ those, who were there, were remarkably well behaved $\&$ appeared to belong to the middle or Bourgeois \& not to the lower class as in England. The Salon is common, as a promenade, to all the persons in the house - it is very long - but not square as in Drury Lane - forming rather a kind of Gallery. It forms a most agreeable promenade between the Acts, \& the most respectable Ladies need not be ashamed to be seen there. ${ }^{12}$ It was impossible not to be struck by the extreme attention to propriety in every respect. As a friend of mine well remarked, it is left for modest England to encourage the admission "des dames de plaisir" - by setting apart a particular portion of the house for their reception. It is the usual custom in France, not to change the scenery during their Acts, but in this Opera, they were obliged to shift them twice during the Evening - they did it admirably. A kind of curtain beautifully painted to represent clouds, arose slowly from underneath the stage, so as to have sufficient time for the scene shifters to make all their $/ 29 \mathrm{v} /$ arrangements. Robert Le Diable has had a most capital run - tonight was its $120^{\text {th }}$ performance, \& though probably rather too long, yet the interest is so kept up during the whole, that one feels very sorry when it is brought to a close. It lasted this Evening from 7 till $1 / 2$ past 11 . It is in five Acts. The principle characters in it are, Robert, Duc de Normandie, Bertram, his friend - discov ${ }^{\mathrm{d}}$. afterwards to be his father, \& a Devil Incarnate - Alice, a Norman Peasant - Isabel, the daughter of the King of Sicily - \& various Monks, Nuns \&c. The plot is not deep - Robert comes to Sicily, attended by Bertram, who leads him into all kinds of temptation, \& at last, attempts to seduce him to give himself to the Devil, on condition of enjoying all this world's goods, \& marrying Isabel, of whom he is devotedly fond. But Alice appears with a letter from Robert's mother, \& succeeds in causing him to

quatre" in the second act and a characteristic ballet in the third act, probably like the dancing the diarist refers to, had been presented at the King's Theatre, Haymarket, and set to music by Giacomo Meyerbeer.

${ }^{7}$ This suggests that although the diarist was from the provinces he was familiar with at least some London theatres including the Drury Lane Theatre mentioned here.

${ }^{8}$ The previous opera houses had been lit by oil and the brilliant illumination produced by gas lighting was considered to be very pleasing.

${ }^{9}$ The standard of technology in the theatre was very high, with an open space 32 feet deep beneath the stage for the machinery for scene changes and the like. Furthermore, in the case of fire, the stage area could be entirely closed off with a sheet of iron material (safety curtain) and ventilators opened to drive the flames in any direction. In addition, there were water reserves in the roof area. (Galignani's new Paris guide, p. 548.)

${ }^{10}$ The internal crowd control measures and the number of outlets was such that confusion on entering the theatre was minimal and the house could be entirely cleared at the end of a performance within ten minutes. (Galignani's new Paris guide, p. 547.)

${ }^{11}$ This suggests that it might have been usual to pay at the door.

${ }^{12}$ He seems to have failed to realise that these "respectable" women would include family members, mistresses and well-dressed courtesans. 


\section{1-3 January 1835}

dedue resist all the seductions of Bertram. The music is very fine, the scenery admirable, particularly the church in the $8^{\text {th }}$ scene of the $3^{\text {rd }}$. Act, when the Ghosts rise up ${ }^{13}-\&$ the dansing $[s i c]$ was inimitable $\&$ certainly much more modest, than I had expected, in France. Altogether I was pleased, \& delighted much beyond my most sanguine anticipations Mmes Cinti Damoreau as Isabel, \& Dorus Gras as Alice ${ }^{14}$ had splendid \& most powerful voices such, as it was never my good fortune to hear before. As for the acting, I cannot say anything about it, as I was too far off to detect minuter shades, \& as I $\mathrm{c}^{\text {ld. }}$. not follow the words, ${ }^{15} \mathrm{I} \mathrm{c}{ }^{\text {ld }}$. of course not understand it, sufficiently, to give an opinion.

130r/ Friday $2^{\text {nd }}$.

Went down to the Hotel Dieu. There were several accidents, such as fractures, burns \&c. brought in since last Evening. Most probably, I think, New Year's Night is something like Xmas Night in England - every person considers himself privileged to get intoxicated - such is also the case in Scotland. ${ }^{16}$ Went to my Salon Litteraire \& was presented with a paper of "Bonbons" - miserable things as ever were - much worse, than anything of the kind in England. ${ }^{17}$ It is the custom in France to present something or other to every body you know $-\&$ to call upon or leave $y^{r}$. card with all $y^{r}$. friends. ${ }^{18}$ Fortunately I know no one \& therefore am free from this nuisance. At Sichel's, nothing very particular. Saw him remove a vascular fungus ${ }^{19}$ from the conjunctiva with a sharp lancet. Bought a copy of Byron today for 15 francs - exceedingly cheap - excellent type. ${ }^{20}$

Saturday $3^{\text {rd }}$.

Went to La Charité this morning. Saw Roux perform amputation of the leg by circular operation - he was a considerable time about it, but very cool. There were three ligatures ${ }^{21}-$ applied adhesive plaster - plenty of sharpie, 6 layers of linen \& a bandage. What is the use of so much? Went to hear the second lecture on Dental Surgery today - he first taught us to use the "Parrot's Bill" forceps ${ }^{22}$ for the incisors of the lower jaw. The head is held firmly as

\footnotetext{
${ }^{13} \mathrm{He}$ had in fact appreciated the special wiring technology available for "raising" actors on to the stage.

${ }^{14}$ The additional printed sheet in Galignani's new Paris guide between pp. 540 and 541 (see note 4 above) has Mmes Cinti-Damoreau and Dorus listed among the principal women performers.

${ }^{15} \mathrm{He}$ does not say whether he was too far away to hear distinctly, or that following French sung by a range of characters was quite different to, and more difficult than, following a single speaker giving a lecture on a medical topic.

${ }^{16}$ The diarist refers to enjoying alcohol, especially champagne, elsewhere in the diary but it would appear from this entry that he had strong views against over-indulgence even on festive occasions such as New Year in Paris and in Edinburgh.

${ }^{17}$ They could have been sugared almonds.

${ }^{18}$ Visiting cards were not exchanged at Christmas in England, and Christmas cards were not introduced until about 1867.

${ }^{19}$ Vascular fungus, fungus haematodes or haematomas: names given to any luxuriant formation of flesh on an ulcer or to a diseased part of a structure such as the testicles, breast and extremities, which enlarges and, as in this case, where the fungus is growing on the conjunctiva, is excrescential and vascular. The disease is sometimes called soft cancer. Medicines against cancer were not effective, extirpation where practical was the only cure.

${ }^{20} \mathrm{He}$ was aware that books were much cheaper in France than in England and over the months he built up quite a collection to take back with him.

${ }_{21}^{11}$ Ligatures: see March 25, note 57.

22 "Parrot's Bill" forceps: a specialised form of the instrument for extracting teeth, also called a "key". It consisted of a firm handle, with a claw, beak or hook, and at the time was generally used for extracting bi-cuspid and molar teeth. For other specialised forceps, see April 13, 17, notes 32 and 38.
} 


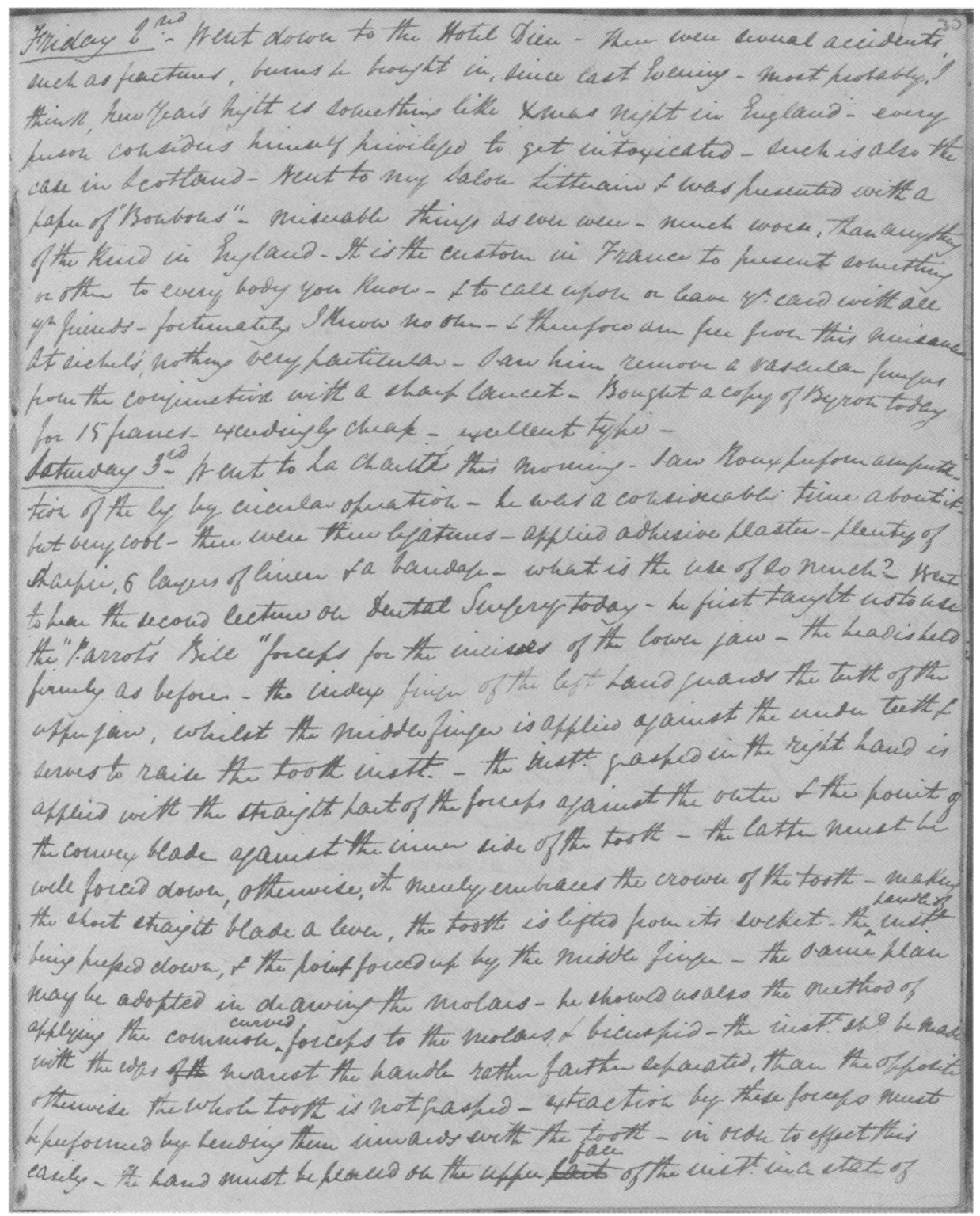

Figure 13: Page 30r of MS 7147, showing the entries for 2 and 3 January 1835. (Photo, Wellcome Library, London.)

before - the index finger of the left hand guards the teeth of the upper jaw, whilst the middle finger is applied against the under teeth \& serves to raise the tooth inst ${ }^{t}$. The inst ${ }^{t}$. grasped in the right hand is applied with the straight part of the forceps against the outer $\&$ the point of the convex blade against the inner side of the tooth. The latter must be well forced down, 


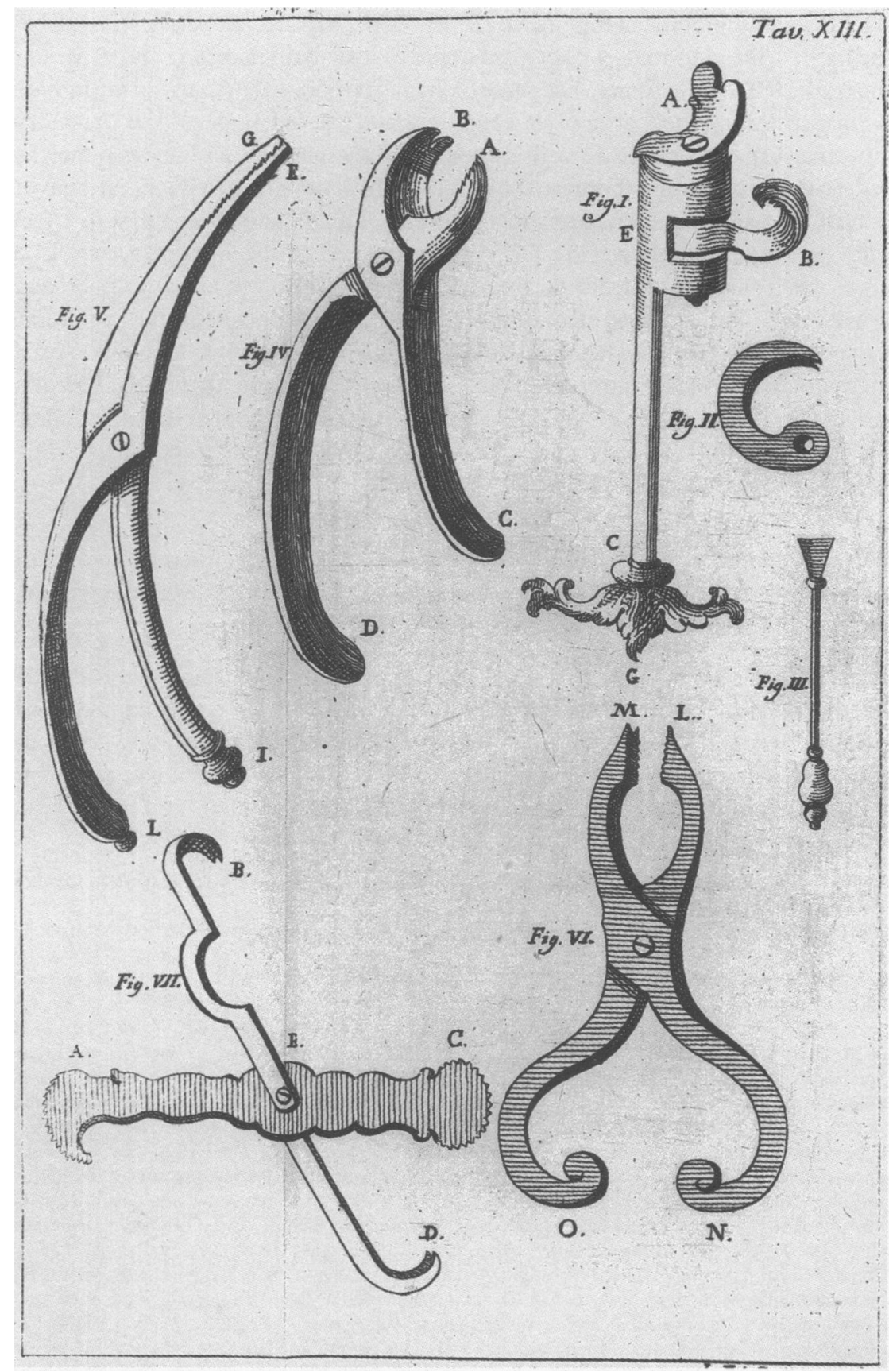

Figure 14: Some eighteenth-century dental instruments. From Mauro Soldi, Descrizione degli' instrumenti ... dal P. Don Ippolito Rondinelli, Faenza, Archi, 1766. (Wellcome Library, London.) 


\section{3-5 January 1835}

otherwise, it merely embraces the crown of the tooth. Making the short straight blade a lever, the tooth is lifted from its socket, the handle of inst ${ }^{t}$. being pressed down, \& the point forced up by the the middle finger. The same plan may be adopted in drawing the molars - he showed us also the method of applying the common curved forceps ${ }^{23}$ to the molars $\&$ bicuspid - the inst ${ }^{t}$. $s^{d}$. be made with the edges nearest the handle rather farther separated, than the opposite otherwise the whole tooth is not grasped - extraction by these forceps must be performed by bending them inwards with the tooth - in order to effect this easily, the hand must be placed on the upper face of the inst ${ }^{t}$ in a state of $/ 30 \mathrm{v} /$ supination, when one of the teeth on the right side of the lower jaw is extracted $\&$ the hand $\&$ inst ${ }^{\mathrm{t}}$. to be turned into a state of pronation - on the opposite of the jaw it must be exactly the contrary - the hand being applied in a state of pronation to the under surface of the inst ${ }^{t}$. \& gradually turned into pronation. ${ }^{24}$ I forgot to mention, that in the Parrot's Bill forceps both legs ${ }^{25}$ must not be on the same level, when they lay hold of the tooth, otherwise the latter may be cut off. I vastly prefer the key for molars, to his forceps.

Sunday $4^{\text {th }}$.

Went to La Pitié this morning. Louis not there, went round with his Interne. ${ }^{26}$ No particular cases there. Miserably cold today - was obliged to take a walk in the sun to warm myself.

Monday $5^{\text {th }}$.

Went to the $S^{t}$. Louis this morning. Biett came very late - some capital cases of Impetigo \& Eczema. These diseases of the skin are uncommonly difficult to understand $-\&$ still more annoying to treat in practice. At Sichel's a considerable number of good cases. Went to Ricord's ${ }^{27}$ today \& obtained a carte of admission to the Venereal

\footnotetext{
${ }^{23}$ Common curved forceps: typical forceps with curved arms suitable for working on teeth in the mouth.

${ }^{24}$ Pronation: see February 16, note 33.

${ }^{25}$ Another instance of French influence. In correct English he would have referred to the "arms" of the Parrot's Bill forceps.

${ }^{26}$ The internes were medical assistants or house surgeons, who were chosen from the best dressers of the previous year and who could be of any nationality. They lived in the hospitals and in 1828 received in addition a salary equivalent to $£ 20$ to $£ 30$ per annum (Rutherford Alcock, in Ratier, Medical guide to Paris, p. 6). They prescribed for the sick in the absence of the professors, generally made evening visits to their wards and could be a source of private instruction. Thus they might take a group of four or five students for a monthly payment each. Such private lessons, which provided bedside experience, the opportunity to handle patients, ask questions and receive answers at their own pace, were particularly important for students - and those from America figured here - whose command of French was imperfect. (Warner, Against the spirit of system, pp. 100-1.) The diarist complained once, and understandably, that it was people like the garçons, who were no doubt using patois expressions, whose French presented some difficulties for him, not that of the professors. As Weisz notes, the post of hospital interne was frequently part of a career path to becoming a member of the élite cadre of doctors, especially in Paris, and even to appointment to the ranks of the Academy of Medicine (Medical mandarins, pp. 237-53). In the Edinburgh Infirmary there was a comparable system of clerkships to which the most successful recent medical graduates, many following advanced medical courses, could aspire. The clerkships were for unmarried individuals, lasted two years and carried an annual salary of $£ 20$. See also December, note 97.

${ }^{27}$ Philippe Ricord (1800-89) was born in Baltimore of French parents and completed his medical education in Paris, where he stayed. He obtained a post in 1831 in the Hôpital des Vénériens du Midi (see this month, notes 28 and 32), which was reserved for male patients. Not surprisingly, although Ricord, like all the lecturers, lectured in French, his manner of speaking it was more comprehensible and hence greatly appreciated by the English-speaking students - especially the Americans, who regarded him as a fellow countryman. He placed much emphasis on symptoms, lesions and the course a disease was taking. (Warren, Parisian education, pp. 47-8.)
} 
Hospital. ${ }^{28}$ I like M.R. very much - he was extremely polite. He must be a clever fellow, or he $\mathrm{c}^{\text {ld }}$. not, at so young an age, have obtained so many honors \& got so much the start of all his confreres. I understand, he is a very neat operator - he lives in a capital house, \& the two rooms that I saw, were well furnished \& more comfortable in appearance, than any I have met with in Paris before. I suppose, the reason of this is, that $R$. is not a Frenchman, but an American. He had several pat ${ }^{\text {ts }}$. waiting for him \& I dare say, manages to pick up a considerable sum by his practice. ${ }^{29}$ This Evening I went to the Eglise St. Etienne ${ }^{30}$ the music was admirable, particularly the Portuguese Hymn. Such mummery ${ }^{31}$ I never in my life beheld before - especially the throwing up \& down [of] the incense box.

/31r/ Tuesday $6^{\text {th }}$.

Went this morning to the Hopital du Midi ${ }^{32}$ - there were some very good cases among the men. I saw nearly 50 women exposed \& examined with the speculum. M. Ricord has some peculiar notions about gonorrhoea in the female - he employs mercury in almost all cases of syphilis - quite an anti Thompsonian $[$ sic $] .^{33}$ I saw Sichel remove by the knife, a large staphyloma - a $\mathrm{ch}^{\mathrm{d}}$., in whom he performed the same operation a few days since, is completely cured. The wound is cicatrized \& the deformity greatly remedied. There was a case of incipient Amaurosis, very much relieved by the application of the following around the eye, three times a day - R Aether : Sulphur : 3 ss Liq: Ammon : $3 i$ _.. M. Lamaire [sic] gave us a lecture today on the application of the $\mathrm{key}^{34}$ to the extraction of the molars of the upper jaw more especially - he always draws them outwards fixing the lever

\footnotetext{
${ }^{28}$ The venereal hospital, the Hôpital des Vénériens du Midi, was established in a former house of the Capuchins. It received patients who had formerly been treated at the Hôtel Dieu and the Salpêtrière. It was the only important clinic for venereal diseases in Paris at the time and Ricord - who remained at the hospital until 1860 - took over the free clinic in 1834 . This became famous for research and treatment of venereal diseases. Whilst the diarist was in Paris, Ricord was investigating experimentally whether or not a "syphilitic virus" could be transmitted by inoculation and if syphilis and gonorrhoea, which in their initial stages appeared to have similar symptoms, were the same disease. Ricord demonstrated that gonorrhoea, whilst contagious, was a local affection having nothing in common with syphilis. He also confirmed that syphilis always begins with a chancre, which, if it remains soft, is never followed by constitutional syphilis. Only when chancres become hard - and it was recommended that chancres be destroyed before this took place - are they contagious. (Rapport sur les progrès de la chirurgie by MM. Denonvilliers, Nélaton, et al., pp. 123-51, cited in Warren, Parisian education, p. 47.) See also November, note 37.

${ }^{29}$ The diarist is indicating that, as in large British cities, physicians and surgeons in Paris would generally, as well as holding a teaching post in a hospital, also run a private practice.

${ }^{30}$ St. Étienne du Mont was the parish church of the 12th arrondissement on the right bank of the Seine.

${ }^{31}$ Mummery: ridiculous ceremonial, referring, in this case, to religious practices in the Roman Catholic church.

${ }^{32}$ In 1808 the Hôpital des Vénériens du Midi set up a free clinic for out-patients and the numbers treated increased over the years, for example, from 978 in 1810 to 1509 in 1813 . Warren claimed that the hospital was re-named the Hôpital du Midi in 1836, but since the diarist is already using that name in 1835 , he was clearly mistaken. (Parisian education, pp. 47-8.) Warner refers twice to "Hôpital du Midi" and once to "Hôpital de [sic] Vénériens du Midi" when apparently referring to the same establishment. (Warner, Against the spirit of system, pp. $82,120,99$.

${ }^{33}$ Thomsonianism, or medical botany, was started by Samuel Thomson (1769-1843) in North America where it became very popular, as it did later in Britain, being taken up particularly by the working classes. It was based on six classes of botanical drugs milder than those prescribed by regular physicians. (Miley and Pickstone, 'Medical botany', p. 140.)

${ }^{34}$ Key: see this month, note 22 .
} 


\section{6-7 January 1835}

within $\&$ the fulcrum without $\&$ the rule he gave us, was to make the latter always rather higher, than the former. The head of the pat ${ }^{t}$. is fixed by the left hand of the operator as before mentioned, forcing it back against the right thigh for the right side \& the left for the left. The thigh sh ${ }^{d}$. rest on the corner of the back of the chair or on the seat of a second. The fulcrum M.L. covers with common Indian Rubber, forming an elastic cap to it - the claw is not like the English, but somewhat in this shape $\supset$ The straightness of the back enables it to be pressed down more easily, by the forefinger, than when made in the common way.

Wednesday $7^{\text {th }}$.

Went to the Hotel Dieu this morning \& to my great astonishment met Bird ${ }^{35}$ there - he left Dover ${ }^{36}$ Saturday last. Went on to the $S^{t}$. Louis - the old cases still there. One new one of Ecthyma, I think, \& an excellent one of Sycosis. ${ }^{37} \mathrm{M}$. Alibert gave us a kind of Clinique the first example, he showed us, was Lupus, cured by caustic, \& Hydrioda ${ }^{t}$ of Potass. Psoriasis. One or two of Impetigo \& a splendid specimen of Sycosis, extending all round from the ears, $\&$ under the chin. The tubercles were of considerable size, nearly as large as marbles - the lymphatic glands in the neck were affected, \& there was considerable salivation - it was of two months standing. Called at the Gen ${ }^{1}$. /31v/ Post Office but no letter for me. ${ }^{38}$ At Sichel's, but few pat ${ }^{\text {ts }}$. One excellent example of Amaurosis, apparently produced by disease of spinal cord, which Sichel said, he had seen more than once, \& attributed to the disease being transmitted upwards to the Tubercula Quadrigemina. ${ }^{39}$ On examining the eye - the pupil is found somewhat dilated, not contracting quite so much, as it ought, on exposure to the light $\&$ at the bottom of the eye - there appears a kind of green shade, which Sichel considered en characteristic. The reason of his imagining, that the disease arose from disorder of the $\mathrm{Sp}^{1}$. cord, is, that pain came on in the back, between the shoulders, after an accouchement, followed quickly by dimness of sight - (Mem: Salmon's case, combined with Paraplegia ${ }^{40}$ ) the treatment adopted, was V.S. 4 Palettes, ${ }^{41}-15$ Leeches between the shoulders. $\mathrm{R}$ Ung: Hyd: $\xi_{i i}$ Laudanum de Rousseau $\xi_{i} \mathbf{M} \mathbf{f}^{\mathrm{t}}$. Ung:

\footnotetext{
${ }^{35}$ As explained more fully in note 37 of the Introduction (see p. 8), it has not been possible to identify Bird. There may in fact have been two people with that surname, one with the initial $J$. The man referred to by his surname alone could have been studying at Edinburgh University, which provided courses for both aspiring physicians and surgeons, at the same time as the diarist.

${ }^{36}$ Dover was Bird's ferry departure point for the Channel crossing to France. There were four principal routes from London to Paris: via Dover and Calais, via Dover and Boulogne, via Brighton and Dieppe, via Southampton and Le Havre. The first two routes were considered to be, as well as the shortest, the surest and most expeditious although not offering the most scenic roads to Paris. The route to Paris from Calais of about 180 miles by carriage (diligence) and measured in "posts" involved about thirty-four posts, whereas that between Boulogne and Paris of about 110 miles involved only about 20 posts. It would seem from the diarist's surprise that Bird travelled to Paris via Boulogne. (Galignani's new Paris guide, pp. xx-xxxvi.)

${ }^{37}$ Sycosis: an inflammatory skin disorder with pustules involving hair follicles, especially those of the beard and scalp. There are some differences in the appearance and progress of the eruptions in these two sites which has given rise to the identification of two varieties of the condition. The treatment is similar to that for porrigo and cure is more easily accomplished. (Hooper, Lexicon, pp. 1176-7.)

${ }^{38}$ He was having his mail sent poste restante since he was likely to change his lodgings during his stay. This was a convenience used by both foreign visitors and long-term residents.

${ }^{39}$ Tubercula Quadrigemina: four white oval tubercles of the brain, two of which are situated on either side. The ancients called them nates (buttocks) and testes from their supposed resemblance.

${ }^{40}$ Paraplegia: paralysis of the lower limbs and a part or the whole of the trunk due to damage or disease of the brain or spinal cord.

${ }^{41}$ Palettes: French term for the large tin saucer-like tray for catching body fluids, in this case blood from the bloodletting, or pus.
} 
applicand: part: dolente dorsi Quater Die. ${ }^{42}$ I can't well see, how this treatment can be of much avail. However it is worth trying. It $w^{\text {ld }}$. probably be not a bad plan to put the pat ${ }^{t}$. under the action of mercury. Saw today a curious case in the Gaz: des Tribunaux. ${ }^{43}$ It appears, that in Paris, there exists a society termed the Society of Devils, which meet every Saturday Evening, in a subterraneous cellar, which they term Hell. They meet to eat, drink, smoke \& sing blasphemous songs. They were arrested \& tried, but nothing $\mathrm{c}^{\text {ld }}$. be proved against them, of which the laws take cognisance, they were accordingly $/ 32 \mathrm{r} /$ acquitted. What an extraordinary people these French must be. In England, such a thing, as this, $w^{\text {ld }}$. never for a moment have been tho ${ }^{t}$. of. By the bye, Alibert, this morning $a$ paid us a very high compliment - he said, speaking of our not adopting his nomenclature - that we were not a scientific nation, but that we observed for ourselves, \& observed well, \& followed out our own notions in practice with success. He is evidently annoyed that we do not adopt more extensively his natural system. ${ }^{44}$

Thursday $8^{\text {th }}$.

Went down to the Hotel Dieu this morning. Breschet not there - went round with his interne. Several cases of old fracture. Inscribed today at the École de Medicine - this will be my last inscription. At 12 entered to a course of Bandaging - at 15 francs - cheap enough indeed. ${ }^{45}$ Nothing particular at Sichel's - nor at Lemaire's - he shewed us how to employ the punch, ${ }^{46}$ with which indeed he elevated a dens sapientia ${ }^{47}$ in our presence very skilfully - but others, who have not his experience, I suspect, will do well to adhere to the key.

Friday $9^{\text {th }}$.

Went to the Hotel Dieu this morning. Sanson performed the operation, for fistula ${ }^{48}$ in anohe introduced the probe ${ }^{49}$ - brought the inner extremity out of the anus, $\&$ then divided upon it, this is by far the most successful method of performing the operation $\&$ he dissected out some of the callous edge of the fistula, \& removed a small fibrous substance growing from the margin of the anus. Attended Chomel's Clinical lecture, $\&$ afterwards went round with Breschet, who was only just arrived (10 1/2 - his time being 9). He has had two cases of varix $^{50}$ of the cord, under his care completely cured by Dupuytren's plan of fixing small

\footnotetext{
${ }^{42}$ This prescription gave instructions for "Ung:" an ointment consisting of "Hyd:" (hydrargyrum) mercury and laudanum to be "factio", made up, and applied to the painful back area (dolente dorsi) four times a day (quater die).

${ }^{43}$ The Gazette des Tribunaux was a newspaper published at 11 Quai aux Fleurs at a cost of 15 francs a quarter. (Galignani's new Paris guide, p. lxii.)

${ }^{44}$ Alibert regarded Willan's approach to the classification of skin diseases as superficial and mechanical. Alibert produced a new classification which was embodied in his "Tree of Dermatoses", which appeared as the frontispiece of his Clinique de l'Hopital Saint-Louis, 1833. He claimed that his system was the "nosologie naturelle" of skin diseases. (Crissey and Parish, Dermatology and syphilology, p. 49.)

${ }_{45}$ The course on bandaging was a private one, hence the need to pay a fee. See this month, note 79.

${ }^{46}$ Punch: an instrument used in dentistry for extracting the stumps of teeth.

${ }^{47}$ Dens sapientia: wisdom tooth.

${ }^{48}$ Fistula: a long sinuous ulcer (in this case in the anal region) that has a narrow opening, which sometimes leads to a larger cavity or to the surface and which shows little disposition to heal. Other fistulae occur in the vaginal area. (Hooper, Lexicon, p. 586.)

${ }^{49}$ Probe: a surgical instrument of long slender form and of a range of sizes, used to investigate the depth and extent of diseased or damaged tissue.

${ }^{50}$ Varix: dilatation of a vein or less often a lymph vessel. Such varicose veins, commonly found in the groins and scrotum, can become serpentine-like and knotty.
} 


\section{January 1835}

forceps of a peculiar construction on the enlarged veins - taking care at the same time to keep the parts constantly wet with solution of Acetate of Lead. ${ }^{51}$ No phlebitis of any consequence is manifested, but the veins become obliterated - frequently superficial sloughing takes place. Another pat ${ }^{t}$. was put under this same treatment. At the $/ 32 \mathrm{v} /$ " Consultation Gratuite" a child was presented, having a syphilitic sore on the buttocks ${ }^{52}$ surrounded to [a] considerable extent by a deep red or copper color. The ulcer was deep greyish white at the bottom, \& with the borders perpendicularly cut - the woman (the mother) denied \&c \&c - but women can never be believed. A man applied with varicose ulcers on the leg. Beschet pointed out this case, as remarkable - varix ${ }^{53}$ occurring in the right, \& not in the left leg. I was not before aware, that the same rule applied to the leg, \& the spermatic cords, in this respect. Went $\&$ bought a skeleton today for 100 francs. I am told it is a bargain, but I am by no means certain of it - however I cannot be much taken in. ${ }^{54}$ It is beautifully articulated. I certainly never saw one better fitted up altogether \& moreover it is a female pelvis I am very sure, tho' the man declares it to be a male. At the course of bandaging today, we went over the "croisée sur un oeil, sur les deux yeux - sur la machoiresur le cou et la tete" ${ }^{55}$ Confound these long French names. At Sichel's, we had some very excellent cases - one of Keratitis \& Pannus ${ }^{56}$ cured by depletion \& a lotion composed of Oxymur ${ }^{2}{ }^{57}$ of Mercury $1 / 2$ gr to $\xi i \& \xi$ ss of Laudanum. Sichel declared today, that authors were wrong in saying, that great intolerance of light always existed in scrophulous ophthalmia. ${ }^{58}$ I have seen, I think, three cases of what he called, strumous ophthalmia, without this symptom. Intended to buy Gerdy on Bandaging ${ }^{59}$ today, but I am so much disappointed in it, that I have given up my intention. I hear that Chapman $/ 33 \mathrm{r} / \mathrm{has}$ published a small edition of his work, ${ }^{60}$ with marginal plates, for at $3 / 6$ - very cheap - must get it, when I go to London.

\footnotetext{
${ }^{51}$ Acetate of lead, also known as Saturn's Salt, could be used in the form of powders, pills, ointment or, for eye and internal conditions, as a liquid. In large doses it could be poisonous but in small quantities it was widely used as an astringent for maladies of the intestinal mucous membrane, including ulcers, for skin inflammations, burns and the like. (Milne-Edwards and Vavasseur, Nouveau formulaire, pp. 43-4.)

${ }^{52}$ Hooper discusses the issue of transmission of syphilis to the foetus in utero or to the newborn at birth. Citing the authority of Dr Swediaur, he inclines to the view that whilst no newborn infant has been observed with ulcerations or other symptoms, those who develop these symptoms up to several days after birth have not been infected in utero but when coming into contact with syphilitic ulcers and "the venereal poison" in the vagina during the birth process; or they could have been infected by the infected nipples of a wet nurse. (Lexicon, pp. 1185-6.)

${ }_{53}^{5}$ Varicose veins are more usually found in the left leg.

${ }^{54}$ Skeletons had become scarce by this time and the diarist's comments suggest that his skeleton may have been constructed from a range of source material.

${ }^{55}$ The diarist is listing the parts of the body and the special bandages of which, in the class, he has gained experience. These include bandaging for a single eye, both eyes, the jaw, the neck and the head.

${ }^{56}$ Pannus: a speck or membraneous excrescence which can grow over areas of the front of the eye. It can be pellucid and painless or thicker and red (vascular) or other colours, painful and sometimes cancerous. In some cases it appears in the external corner of the eye, is fatty and yellow and remains throughout life. (Hooper, Lexicon, p. 928.)

${ }^{57}$ Oxymure: oxymuriate of mercury is mercuric chloride also known as "corrosive sublimate".

${ }^{58}$ Scrophulous ophthalmia: inflammation of the eye which, in this case, being scrophulous (involving swollen glands), affects the sebaceous glands of the eyelids whose discharges overnight cement the eyelids together. (Lexicon, p. 906).

${ }_{59} \mathrm{He}$ is probably referring to: Pierre Nicolas Gerdy, Traité des bandages et appareils de pansement, Paris, 1826.

${ }^{60}$ In his Introduction, H. T. Chapman states that "Surgical apparatus comprehends, Bandages of all kinds; Apparatus for Fractures, Apparatus for reducing Dislocations, and Instruments ...”. The section on bandages, the first in the work, is by far the longest. (A brief description of surgical apparatus, p. 1.)
} 
Saturday $10^{\text {th }}$.

Went down to the Hotel Dieu. Breschet was there very early this morning - precisely 9 o'clock. Nothing particular. At the course of bandaging, we went over those, we had before applied. I think it will probably be an instructive course - will teach us, how to handle a bandage at all events. Went to the Louvre - it will be closed in a few days, so it is necessary to see as much of it as possible within a short time - it was excessively cold - I sh ${ }^{d}$. think it must be one of the most splendid galleries in the world - at least I can scarcely imagine anything finer - tho' had Napoleon existed, \& had the foreign spoils remained in Paris - there is little doubt, but that all the four sides of the square $w^{\text {ld }}$. have been turned into one grand gallery. ${ }^{61}$ At 3, went to Lamaire's - I think I learnt something today - he extracts stumps in the front of the upper jaw by drilling a hole $\&$ introducing a screw, the projecting extremity of which he lays hold of with the forceps - this is rather too complicated for general use - he says, that teeth particularly incisors are extracted, when there is no necessity for it - to avoid this, it is proper to file down the decayed portion, $\&$ remove it entirely with a cutting inst ${ }^{t}$. - the files must be very thin, having one smooth, \& three rough edges or surfaces - by the latter of course the tooth is filed, whilst the smooth surface comes against the adjoining tooth - the file is introduced obliquely so as to remove more of the posterior than the anterior aspect - it is of the utmost consequence to press firmly with the thumb of the left hand against the root of the tooth acted on by the file - as otherwise there is a good deal of pain produced. The operator $s^{d}$. stand as nearly as possible on the right $\&$ in front of the pat ${ }^{t}$., with his left arm encircling the neck, the thumb pressing on the root of the tooth - the second finger in the mouth to guard the file from coming in contact with the mucous memb $b^{e}-$ the remaining $/ 33 \mathrm{v} /$ fingers under the lower jaw - the file must be held between the thumb $\&$ index finger of the right hand, \& the filing motion kept up by motion of the wrist, making the arm, as nearly as possible, a fixed point. It is of the utmost consequence to file down completely to the gum, \& to separate any little tartar, ${ }^{62}$ which may connect the unsound with the neighbouring teeth.

Sunday $11^{\text {th }}$.

Went to the Hop: La Pitie this morning - went round with Louis \& Velpeau. Nothing particular there - went to Eglise $S^{t}$. Etienne to hear grand Mass ${ }^{63}-$ too late - it had

\footnotetext{
${ }^{61}$ The Louvre: in July 1793 the National Convention had ordained the establishment of a national museum which later became the Musée Royal at the Louvre. Whilst the Louvre was open to the public on Sundays, "strangers", which presumably included foreigners like the diarist, were admitted every day except Mondays "by a door to the right of the principal entrance, upon producing their passport". Its grand gallery, which connected the palace of the Louvre with that of the Tuileries, contained 537 pictures by the great masters of different schools, together with many bronzes and other objects. In 1797-8 a great many other pictures from various European countries were added by Napoleon. Following the occupation of Paris in 1815, many of the most valuable pictures were removed and replaced by pictures from the Luxembourg and other collections. In fact, the director of the Louvre had also under his superintendence the museums of the Luxembourg and Versailles, as well as the galleries of the different palaces. (Galignani's new Paris guide, pp. 491-501.) It is possible that the diarist's evident interest in visiting the Louvre had been encouraged by Gerdy who only a few years earlier had published Anatomie des formes extérieures du corps humain, appliquée à la peinture, à la sculpture, et à la chirurgie, Paris, 1829.

${ }^{62}$ Tartar: deposit, containing phosphate of lime, from saliva which settles on the teeth forming an incrustation around them. Hooper recommends rubbing the gums with an earthy dentifrice as the best prophylactic against the condition (Lexicon, p. 1195). In the seventeenth century pumice was used and later myrrh and camphor were included in such preparations.

${ }^{63} \mathrm{He}$ means High Mass.
} 


\section{January 1835}

concluded - called on Bird not at home - went to the Gen'. Post Office - found a very interesting letter from Wincanton - Eastment ${ }^{64}$ writes well - he asks me how I like the French women - My answer $w^{\text {ld }}$. be, not at all - they are a set of indelicate, disgusting brutes - one may probably, when in the "blues", ${ }^{65}$ laugh one's spleen ${ }^{66}$ for an hour in their company - but they are fit for nothing else ${ }^{67}$ - to know an English woman, it is necessary to see her in the midst of her family by her own fireside - this is her pleasure, this the happiness of her life. The French women on the contrary know no such real "bonheur" as this - their's is all tinsel \& ornament \& however E: Bulwer may exclaim against our own fair countrywomen for their domesticity $\&$ as he calls it their spirit of exclusion - their modesty timidity $\&$ reserve, I adore them for these qualities - they form the most prominent \& the most beautiful objects in this picture to my mind. As to the beauty of the French women I have not yet seen so much as I expected - I have certainly seen many more beautiful in my own country - Some time since a woman wrote in $/ 34 \mathrm{r} /$ the Reformation Newspaper ${ }^{68}$ a very talented article on the abolition of marriage - surely a most delicate subject for a female to handle in a public journal. The Sect - the $S^{t}$. Simonians ${ }^{69}$ is increasing every day in Paris \& no wonder - when their females set such an example of barefacedness \& indecorum - this, forsooth is the nation which styles itself "par excellence" the most civilised in the world. If civilisation consists in breaking asunder all the social laws \& all the ties of society which bind one man to another, then indeed I acknowledge they have reached a pitch of refinement which I hope \& trust is still very very far distant from the English. Heard a most excellent sermon from $\mathbf{M}^{\mathrm{r}}$. Newstead - he has such an extlente admirable method of preaching - very eloquent $\&$ brings forward so many admirable similes \& illustrations to explain his meaning-I am more \& more delighted with him-he commenced on the necessity of religion when young - he compared the righteous man to a sensitive plant, which shrunk

\footnotetext{
${ }^{64}$ Eastment was possibly John Willot Eastment listed in the 1849 London and Provincial Medical Directory (p. 307) as a general practitioner in Wincanton, Somerset, who had qualified in 1818 with an MRCS and an LSA. This may have been the doctor to whom the diarist makes reference in an earlier entry, as someone to whom he would write. Eastment, who may have been the diarist's general practitioner in Somerset, was clearly not above raising the issue of women in a somewhat titillating context with the younger man. Hunt \& Co's Directory and topography of the town of Wincanton, in 1850, lists John Willot Eastment and James Surrage as partner surgeons at an address in the High Street. http://www.uk-genealogy.org.uk/england/Somerset/towns/ W/Wincanton.html.

65 "Blues": an abbreviation of the colloquial expression "blue devils", in use since the eighteenth century, meaning depression of spirits or despondency.

${ }^{66}$ The spleen was regarded as the seat of laughter as well as of melancholy or morose feelings.

${ }^{67}$ One of several instances where the diarist displays what might be taken as post-Napoleonic xenophobia with regard to French men and women. His views on the women are more flexible than those on the men.

${ }_{68}$ It has not been possible to trace this newspaper in either England or France.

${ }^{69}$ In the early 1830s in France, socialist ideas spread, along with republicanism, but as Louis Philippe's government found its footing, these movements suffered setbacks and seemed to disappear. They flourished again in the 1840s. The first well-known socialist appearance was made by the Saint-Simonians. Their leader, Claude Henri de Saint-Simon, had died in 1825 but his disciples Armand Bazard and Prosper Enfantin attracted much attention in Paris with their public lectures, their newspaper Le Globe, and by living with a few followers in a highly organised family - what would probably be called a commune today. They did not enjoy mass support and their quarrels about rituals and whether free love was the best way to emancipate women discredited the organisation, and the government prosecuted them, imprisoning some. But they left strong intellectual influences concerning, for example, the value of scientific knowledge and its importance for developing a humanitarian society whilst promoting economic and industrial development. They were considered by some to be more paternalistic than liberal and egalitarian. (Beik, Louis Philippe and the July Monarchy, p. 38. See also F. Manuel, New world of Henri Saint-Simon, p. 2.)
} 


\section{1-12 January 1835}

[sic] from the pollution of the touch of the human hand. And again in speaking of its being unnecessary to be gloomy in religion - he used the comparison of passing thro' a dark passage $\&$ arriving at a brilliantly lightened apartment, or thro' a dark street, before coming to one's home - the dark passage referred to repentance, $\&$ the chamber to the state of man's mind afterwards - these similes he followed out most admirably. Went again in the Evening - he was on the necessity of self examination \& of employing every moment of our lives - not frittering away or "killing time" in common parlance. ${ }^{70}$

Monday $12^{\text {th }}$.

Went this morning to $S^{t}$. Louis - Gibert went there earlier than usual, \& had finished the visit to the wards before our arrival - he runs thro' the wards very rapidly. At the consultation we had several very good cases, particularly one or two of exzema [sic] \& lichen /34v/ of the hand, simulating very closely to the Itch. The more I see of this disease - the more certain I am, that if the French Pathologists be correct, the English are constantly marking down cases as Itch, which belong in reality to very different diseases. At 12 I went to my course of bandaging - but Monday being a lecture \& not a repetition day, it was not very interesting. By the bye at the $S^{t}$. Louis this morning, a very amusing spectacle occurred - Dr. J. Bernard of Clifton ${ }^{71}$ was there, $\&$ one of the pat ${ }^{\text {ts }}$. was a German who $c^{\text {ld }}$. not speak French - so M. Gibert enquired, if any Gent ${ }^{\mathrm{n}}$. were present, who $\mathrm{c}^{\mathrm{ld}}$. interpret for him. Dr B. immediately stepped forward, \& said he $\mathrm{c}^{\text {ld }}$. speak German - upon this, Gibert asked him to inquire the name of the man-D. B. began to hum \& ha $\&$ at last, burst forth with the expression - "Dear me, what is name in German" - he $c^{\text {ld }}$. not get on, became very confused \& red \& we all enjoyed a most hearty laugh at his expense. ${ }^{72}$ Why will persons come forward \& make themselves such fools? - his vanity \& self esteem must have been not a little piqued, at finding himself in such a dilemma, when he expected to shine, \& to outstrip all the persons around him. At Sichel's, we had some very good cases, particularly of Keratitis \& Iritis \& one case of strumous ophthalmia without much intolerance to light - Sichel says, that the latter symptom is never present without sclerotitis, \& some affection of the retina, \& hence is by no means always perceived in strumous ophthalmia. I see by today's paper, that M. Bichat the Editor of the Tribune ${ }^{73}$ has been fined 6000 francs, \& been condemned to 6 months imprisonment, for translating an article from the Sun Newspaper. Truly this is the land of Liberty!! - When I mentioned this to a Frenchman - his answer was, the Government of

\footnotetext{
${ }^{70}$ This so-called Protestant ethic was a sentiment common among contemporary dissenters. Marshall Hall's wife was of the opinion that he made use even of the time most people threw away. (Hall, Memoirs of Marshall Hall, p. 218.)

${ }^{71}$ James Fogo Bernard, MD Cantab., FRCP London, resident in Clifton, was one of the physicians to the Bristol Infirmary. (London and Provincial Medical Directory, 1849, p. 266.)

${ }^{72}$ It is interesting that the diarist so enjoyed this humiliation of someone from his own part of the country. Was it because Bernard was already a physician with an MD from Cambridge who held a hospital appointment, whereas the individual who may have been his father was a non-graduate practitioner in Clifton with only MRCS?

${ }^{73}$ The Tribune was a republican newspaper which would have supported the Revolution and which continued to advocate reform. Russell Jones points to the government's lack of popular support at the time, its timid foreign policy and such projects as building a ring of forts round Paris. The trials of the republican journalists, such as that of the Tribune's editor, and of leaders of secret societies provided the accused with a public forum from which to denounce the repression of individual liberties. (Warren, Parisian education, p. 61.) See also entry for May 12.
} 


\section{2-13 January 1835}

$\mathrm{July}^{74}$ is very poor - \& in order to replenish its exchequer, it is necessary to levy fines - their motto is - we grant you liberty of the press, you may write what you please, but you must pay for it.

Tuesday $13^{\text {th }}$.

Went to the Hop: du Midi this morning - there was a boy there with gonorrhoea ${ }^{75}$ which M. Ricord cured in rather an $/ 35 \mathrm{r} /$ unusual manner - last week, he introduced the Porte Caustique $^{76}$ de M. Lallemand - (a silver canula) into the urethra. Thro' this, he introduced a stick of $\mathrm{Nit}^{\mathrm{r}}$. of Silver, withdrew the former so much as just to allow the caustic to protrudehe then withdrew both from the urethra - making the extremity move in such a direction, that the mucous membrane was cauterised thro' its whole extent in a spiral line. A slight ichorous discharge ${ }^{77}$ came on the following morning, together with some increase of the gonorrhoea. M.R. then used injections of solution Acetate of Lead \& all disch ${ }^{\mathrm{e}}$. quickly stopped without being followed by any bad consequences. He has been for several days quite well. This is an expeditious plan of curing a terribly tedious disease, $\&$ as such, it is worth being kept in recollection. There was another pat ${ }^{t}$. in the ward, which M.R. called Fra------- I can't imagine for what reason. The penis was covered with the prepuce - but at this part appeared amazingly swelled out. From the point projected some very large excrescences. M.R. divided the prepuce back to its junction with the gland. The latter was found completely covered, as well as the inner surface of the prepuce, with excrescences of various sizes. These M.R. removed with the scissors, \& ordered a simple dressings. Did not remain to see the exposure of the women. ${ }^{78}$ At Ribail's we continued applying the bandages of the head. ${ }^{79}$ At Sichel's nothing very particular - except a cyst in the lower eyelid, which he opened at the inner side \& touched with caustic. M. Lemaire was ill, \& consequently did not give any lecture. Velpeau tied the carotid artery about 8 days ago for Aneurism ${ }^{80}$ by

\footnotetext{
${ }^{74}$ Government of July: the revolution of 27-29 July 1830 overthrew the restored Bourbon monarchy of Charles X and substituted the constitutional monarchy of Louis Philippe. His rule (1830-48) is sometimes referred to as the July monarchy.

${ }^{75}$ Gonorrhoea: it is not clear whether the diarist is referring to a not uncommon non-venereal condition in the young which is unassociated with intercourse and which involves involuntary discharge of semen without copulation. Since metallic salts were common among the stimulants used and since the diarist goes on to name silver nitrate as the remedy prescribed, it seems that the boy's condition may have been the clap. (Hooper, Lexicon, p. 628.)

${ }^{76}$ Porte Caustique: a slim caustic holder especially for administration of substances to the urethra.

${ }^{77}$ Ichorous discharge: a thin, watery, acrid discharge.

${ }^{78}$ Presumably he means exposure of the external urino-genital parts of women diagnosed with venereal conditions who were to be treated by Ricord.

${ }^{79}$ Ribail held the private sessions on bandaging for which students paid a fee. Larousse médical contains illustrations of such bandages (pp. 132-5). Ribail was probably an interne, and may have been the J. Ribail who later presented a thesis (No. 184), Des causes, des signes et du traitement de fracture du tibia, to the Faculté de Médecine, published by Imprimerie et Fonderie de Rignoux, 1839. Bandaging played an important part in the treatment.

${ }^{80}$ Aneurism: a tumour formed by the dilatation of an artery. Three species of aneurism were recognised. True aneurism was identified by the pulsation of the tumour. The danger of such tumours was that they could burst and the patient bleed to death. False aneurism occurred where there was an aperture in the artery through which the blood gushed. It could result from an artery being lacerated in violent exercise, but the most common cause was a wound, especially in the bend of the arm during inept bloodletting. Varicose aneurism occurred when the brachial artery was punctured in opening a vein during bleeding. (Hooper, Lexicon, pp. 119-21.) According to the diarist, this aneurism was not initially serious enough to have required the ligatures which Velpeau seems to have used unsuccessfully.
} 
Anastomosis in the temple. The ligatures have come away, \& secondary haemorrhage has occurred three times - if he don't [sic] take care, the pat ${ }^{t}$. will slip thro' his hands. It is very shameful practice to perform the operation in such a case as that - the tumor was very small had not increased for a twelve month - \& M.V. did not try any of the usual methods adopted in England. The more I see of French Surgery, the more I am disgusted with it.

/35v/ Wednesday $14^{\text {th }}$.

Went to the Hop ${ }^{1} S^{t}$. Louis this morning - went to M. Lugol's ${ }^{81}$ ward, but he sent out word, that he was poorly $\& \mathrm{c}^{\mathrm{ld}}$. not go round - this is the second time, he has served us this trick, confound him - "there is more to this than meets the eye". He was no more ill than I was, for soon after having thus sent us away, he went round the wards with his clerks. I am determined, I will shift out this. I will come every Wednesday morning, 'till he allows me to go round. Is he alone to domineer over the students - he must be taught better, a scrophulous quack - ignorant of cutaneous diseases. ${ }^{82}$ Went thro' the Salles of M. Emery ${ }^{83}$ they are entirely devoted to pat ${ }^{\text {ts }}$. affected with the itch and Porrigo - for the latter affection his remedy was a Pommade of S: Carb: Sodae $\xi s s$ Axung: $\xi_{i}{ }^{84}$ There are several pommades of similar kind in Edwards' Formulaire. ${ }^{85}$ Went to Alibert's Consultation \& lecture there were some capital cases, one of Syphilitic Lichen ${ }^{86}$ - one of Elephantiasis of the Greeks - one a miserable example of sycosis. A splendid case of scrophula ${ }^{87}$ in the cheek

\footnotetext{
${ }^{81}$ Jean G. A. Lugol (1786-1851) was one of the staff on the medical wards in the hospital and, like other colleagues, was engaged in research. He was particularly supportive of the importance of treatment with baths. Between 1819 and 1820 Lugol was engaged in an extensive series of investigations both with relation to the number of patients and the range of treatments used. Lugol dismissed the notion of itch being the result of an ascarid worm or of any other animalcule and claimed that it could be cured more or less quickly by stimulants applied to the skin in the form of baths, fumigations, lotions and frictions, and that the internal treatments then currently favoured were generally useless. (Ratier, Medical guide to Paris, pp. 69-70. )

${ }^{82}$ The diarist is perhaps unaware of Lugol's contribution to the research on skin diseases and of the problems of fitting it in with his general hospital workload.

${ }^{83}$ Édouard Émery (1788-1856) was a physician at the St. Louis hospital. (Wiblin, Student's guide, p. 36.)

${ }^{84}$ The ingredients of the pomade are S. Carb: Sodae = sous-carbonate de soude, a small amount of carbonate of soda, mixed with Axung: = Axungia, the general term for a fat or lard-like substance or oil of turpentine as a common constituent for a pomade or ointment. This is given as a treatment for prurigo (porrigo) in Milne-Edwards and Vavasseur, Formulaire pratique, p. 191.

${ }^{85}$ Milne-Edwards and Vavasseur describe the prescription given by the diarist as "Pommade contre le Prurigo ... dite Pommade no. 4. H. St. L." (p. 191), indicating that it originated in the St. Louis hospital. Other prescriptions indicate other Paris hospitals as their source.

${ }^{86}$ Syphilitic lichen: the lichens had long been recognised among skin diseases from the time of Hippocrates and persisted in the classifications of Willan and Bateman. (Crissey and Parish, Dermatology and syphilology, pp. 2, 8, 148-9.) Hooper does not consider syphilitic lichen either under the group of lichens or under syphilis (Lexicon, pp. 770-3). But he does include a reference to syphiloid conditions, a group of diseases which resemble syphilis and could be regarded as pseudo-syphilitic conditions such as bastard pox, described by John Hunter in his Treatise on the venereal disease (1786). They do not always respond to treatment with mercury.

${ }^{87}$ Scrophula or scrofula: this disease, also known as cutaneous tuberculosis, affected mainly children but could occur in adults. It was characterised by so-called swine swellings, to which swine were also subject, and was considered a condition difficult to define. The tumours occurred in various parts of the body but especially on the neck, behind the ears and under the chin. The joints could also be affected. According to Hooper, Cullen associated the disease with a particular constitution of the lymphatic system. The tumours eventually degenerated into ulcers. The condition was not contagious but thought to be of an hereditary nature and one which could lie dormant in an individual throughout life. Treatments included administration of cinchona, mercurials and anti-scorbutics such as sarsaparilla, coltsfoot, lime-water and, more rarely, iodine. (Lexicon, pp. 1105-7). In earlier times the disease was said to respond to the "touch" of royalty and was known as the King's Evil. (Crissey and Parish, Dermatology and syphilology, pp. 196-7. )
} 


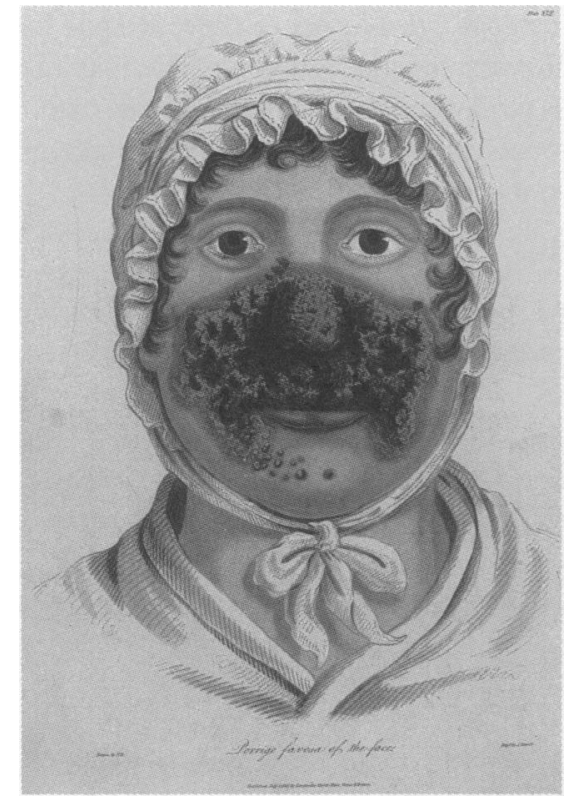

Figure 15: Porrigo favosa, normally a disease of the scalp but here affecting the face. From Thomas Bateman's Delineations of cutaneous diseases, London, H. D. Bohn, 1840. (Wellcome Library, London.)

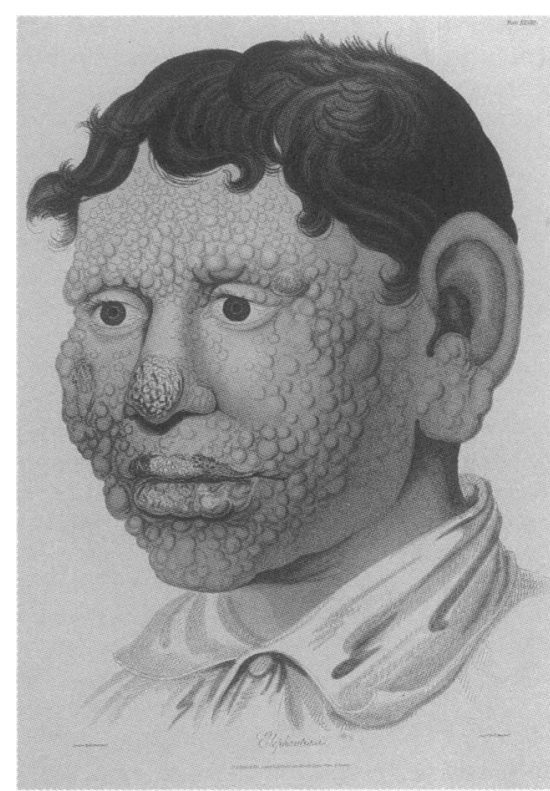

Figure 16: Elephantiasis. From Thomas Bateman's Delineations of cutaneous diseases, London, H. D. Bohn, 1840. (Wellcome Library, London.) 


\section{January 1835}

nearly cured by Iodine, internally \& externally. Another of prurigo \& Itch mixed together $\&$ one of prurigo, which had existed for 50 years. Not much chance of being able to cure it now. At the lecture today, there were four Spaniards who were travelling thro' France. One of them brought his wife \& they all remained to hear the lecture. Very bad taste, I think, in a lady - but these foreign females are all alike. There is no sense of modesty or decency in them. Went to Ribail's today - he practised several bandages. At Sichel's, had some very good cases. Received a letter from Clifton this afternoon - it contained a little election intelligence, ${ }^{88} \&$ an account of an interesting case of toxicology, which occurred in Bristol. ${ }^{89}$ A woman who died fifteen months ago, \& was buried privately in $\mathbf{S}^{\mathbf{t}}$. Augustine's Ch. Yard was suspected to have been unfairly dealt with. Her body was exhumed - the stomach was in an extraordinary state of preservation, whilst the $/ 36 \mathrm{r} /$ body was turned into adipocere $^{90}$ - the stomach was examined by surgeons - there was a good deal of Sulph ${ }^{\mathrm{t}}$. of Arsenic $^{91}$ apparently. This was subjected to various tests, that of reduction, reoxidation $-\&$ three liquid tests, Ammon'. Nit ${ }^{\mathrm{e}}$. of Silver, Ammon ${ }^{1}$. Sulph ${ }^{\mathrm{t}}$. of Copper \& Sulpht ${ }^{\mathrm{d}}$. $\mathrm{Hyd}^{\mathrm{n}} .^{92}$ - these all proving satisfactory. The woman of the Lodging House was arrested \&

\footnotetext{
${ }^{88}$ Following the Reform Act of 1832 there was still considerable political instability between the two main parties of Whigs and Tories. After the short-lived caretaker administration under the Duke of Wellington, the reforming Tory prime minister, Sir Robert Peel, formed a minority government in December 1834. To rally the Tory cause, he had issued his Tamworth Manifesto in December 1834. The general election, referred to in the letter just received by the diarist, took place in January 1835, and Peel gained about eighty more seats for his mild reforms of state and ecclesiatical institutions. Peel was, however, defeated by a Whig-Radical-Irish agreement known as the Lichfield House compact on the issue of the revenues of the Irish Church (to which the diarist makes reference on more than one occasion) and he resigned in April 1835. The Whig, Lord Melbourne, took up the reins as prime minister and was accused by a "Conservative Whig" of being under the influence of "mob and priesthood". (Evans, Modern state, pp. 225, 308-9.)

${ }^{89}$ The case was reported prominently and at length in The Times on 2 January 1835 under the headline: "Extraordinary case of suspected murder at Bristol". The inquest, held at the Ship Inn, Bristol, before Mr J. B. Grindon, coroner, "and a respectable jury", concerned the death of Mrs Clara Smith, who had been a lodger of Mrs Wade (since Mrs Smith's death she had remarried to become Mrs Burdock) in Trinity Street, Bristol. The landlady had employed Mary Ann Allen, a witness, aged sixteen at the time of the inquest, to stay and sleep in the same bed with Mrs Smith. Mary Ann noticed that Mrs Smith was very ill and, during her second night's vigil, she saw the landlady feeding Mrs Smith some gruel that had been prepared downstairs out of her sight. Mrs Smith developed pains, spat blood and soon died. Mary Ann was paid 6s. for her work and ordered to tell no one of the death. During the laying-out she had removed a pair of large carnelian earrings, which the landlady declared would "help to bury her", since, it was claimed, Mrs Smith was dirty and poor. A second witness, Mr Henry Thompson, employee of Mr Thomas, the undertaker, had identified the exhumed body as that of Mrs Smith "by the trimmings". A third witness, Thomas Manley, was the deceased's nephew, who had also identified the exhumed body from the hair colour and two prominent front teeth. He considered his aunt to have been worth $£ 2,000$ to $£ 3,000$, which she kept in boxes in one of which he had seen at least 600 sovereigns. She had also possessed many gold rings and a gold watch. The following day, after forty minutes deliberation by the jury, the coroner returned the verdict that "we find the death of Clara Ann Smith was occasioned by arsenic, administered by the hands of Mrs Burdock". (The Times, 3 January 1835.)

${ }_{90}$ Adipocere: wax-like substance formed from fatty tissue after death. It is especially noticeable in human bodies buried in damp places.

${ }_{91}^{91}$ Sulphate of arsenic preserved the stomach from turning to adipocere.

${ }^{92}$ Ammon $^{1}$. Nit ${ }^{e}$. of Silver: ammoniacal nitrate of silver; Ammon'. Sulph ${ }^{i}$. of Copper: ammoniacal sulphate of copper; Sulph ${ }^{\text {td }}$. Hyd ${ }^{\mathrm{n}} .:$ sulphurated hydrogen or hydrogen sulphide. The substances cited here were the reagents used in forensic testing for poisons, such as arsenic, in body tissues. According to Hooper, Dr Marcet modified Joseph Hume's test of 1809 for arsenic using silver nitrate, by adding ammonia. (Lexicon, pp. 989-96.) See [Joseph Hume], 'Mr Hume's method of detecting arsenic', in the Philosophical Magazine, August 1812. Hume contributed to the same publication in October 1812, 'Additional observations on the detection of arsenic', and in December 1812, 'Observations on the similarity of silver and copper in their application for the detection of arsenic'. See also Jane Marcet, Conversations on chemistry in which the elements of that science are familiarly explained and illustrated by experiments, 1806.
} 
sent to prison on the Coroner's warrant of "Wilful Murder" - By the bye two more haemorrhages have occurred in that unfortunate pat ${ }^{\mathrm{t}}$., on whom Velpeau operated - he will die, I fear, \& I am sure Velpeau, if he thinks for one moment, cannot have a very quiet conscience. He will have most assuredly caused his death, either from his ignorance, his unskilfulness or his unjustifiable boldness.

Thursday $15^{\text {th }}$.

Went to La Pitié today. Louis commenced his Clinical Lectures on Medicine. I like him very well, as a lecturer. At M. Ribail's, went over a few of the bandages. At Sichel's, some good cases - Lemaire gave us a lecture on stopping teeth - he said, that in France common tinfoil was almost invariably used, because they charged so little, only $3 \mathrm{fr}$. but in England, where the price was higher, they employed gold leaf. ${ }^{93}$ The method consists in thrusting in the tin foil, by a kind of bent probe - after having cut out the carious portion, first by a hook, \& then by a sharp pointed knife. If there be much pain, stopping $\mathrm{sh}^{\mathrm{d}}$. not be had recourse to, because fresh inflam ${ }^{n}$. $w^{\text {ld }}$. be induced. Teeth may also be stopped by the following composition: $8 \mathrm{p}^{\text {ts }}$. of Bismuth -3 Tin -10 Mercury -5 Lead. ${ }^{94}$ This alloy melts at a very low temperature. It may be obtained "chez M. Quesneville, Rue de Colombier 33". ${ }^{95}$ A piece of this metal is placed on the hollow of the tooth - a bent probe heated sufficiently is placed on it, so as to melt it \& cause it to run into every crevice of the tooth. The objection to this plan, is that, when it grows cold, it contracts \& consequently does not fill the whole hollow. It is of course difficult to manage in the upper row. When it is properly melted $/ 36 \mathrm{v} /$ the finger must be rubbed on the part, so as to wipe off every particle which projects beyond the neighbouring portion of the tooth. Previously to stopping it, the cavity must be well wiped out by cotton. This being the anniversary of Moliére's ${ }^{96}$ birth - it is a great day at all the theatres hence I have determined to go to the Theatre Français ${ }^{97}$ to see two of Moliére's plays performed. Went to the Theatre - the plays were Le Misanthrope and Malade Imaginaire two excellent pieces. I had a volume of Moliére before me, \& I found it very easy to follow the actors. The house will contain 15,00 [sic] persons ${ }^{98}$ - it was well filled - it is neat - but not so handsome, I think, as the Academie of Musique - \& not nearly so large. We obtained

\footnotetext{
${ }^{93}$ This comment suggests that in both France and England the cavity was, in this procedure, lined with tin foil or gold leaf, and that there was an awareness of the problem of infection.

${ }^{94}$ The amalgam used in this cheaper process is already mixed to form a solid, and the cavity in the tooth was filled almost in the manner of soldering. This would seem more effective than the previous procedure, despite the problem of contraction of the amalgam on cooling.

${ }_{95}$ M. Quesneville is listed in the Almanach général (p. 584) as a producer of chemicals for medical and pharmaceutical purposes.

${ }^{96}$ The diarist is in general careless in his use of French accents. Molière is consistently spelled Moliére.

${ }^{97}$ The Théâtre Français and the Odéon - two of the royal theatres - were the only theatres in Paris at the time where regular tragedy and comedy were performed. The Théâtre Français was devoted mainly to the masterpieces of the chief French dramatic writers, including Molière. Writers received royalties from the performance of their works and all theatres and places of amusement paid a tenth of their receipts to the poor. At the same time the five royal theatres received an annual grant from the government of $1,400,000$ francs (approximately $£ 5,000$ ). Whilst the actors originally wore the dress of French courtiers with the huge wigs of the time of Louis XIV, innovations involved first the exclusion of the feathered hats and hoops of the female characters and later the introduction of costumes appropriate to the character and even the country of the play's setting. The Odéon was the first Parisian theatre to be lit by gas. (Galignani's new Paris guide, pp. 537-45.)

${ }_{98}$ The capacity of the theatre was actually 1,522 seats.
} 


\section{January 1835}

very good seats, nearly in the middle of the Parterre. ${ }^{99}$ I saw some very pretty girls, in the boxes, particularly one, who, I am convinced, was an English beauty, from her appearance, her dress, \& above all, from the gentlemanly appearance, \& deportment of an elderly man, her father most probably, with her. Her face was exceedingly sweet, pleasing \& intelligent, her forehead in particular, was much superior to that of most females, either in our own or other countries. In the Misanthrope Mademoiselle Mars, ${ }^{100}$ in the character of Cèlimène $^{101}$ was the Great Attraction. She is consid ${ }^{d}$. the first Actress of Genteel Comedy in France. She is, they say, $56 \mathrm{y}^{\mathrm{rs}}$. old, but when on the stage - she does not look more than 25 . She is a very fine woman, with a regular, well proportioned face-not certainly what $w^{\text {ld }}$. be called beautiful - but her smile \& method of speaking were absolutely enchanting. I might have looked at her the whole Evening without understanding the language, \& come away perfectly satisfied with the night's Entertainment. The play, I think, was poor. I know I am displaying bad taste, in speaking thus of one of Moliére's plays, but it was so different from an English /37r/ comedy of the same class, that without $\mathbf{M}^{\mathrm{e}}$. Mars, it $\mathbf{w}^{\text {ld }}$. have been very dull. There was no change of scenery during the whole piece, not even between the acts. I do not mean to say, but that in England, the scenes may be changed too frequently, but that fault is certainly preferable to having one unvarying scene during the whole piece. One becomes soon tired of seeing the same house, the same unvarying dresses. One requires some novelty. The drop curtain is remarkably fine - painted so as to represent velvet decidedly one of the handsomest I have ever seen. ${ }^{102}$ The second piece, Malade Imaginaire, is a trifling, laughable, comedy, one which will well suit such a nation as the French, but no other in the world. The old Malade keeps talking about "Lavements, Purgation" \&c, ${ }^{103}$ which seemed to amuse amazingly the French Ladies. There are two or three capital comic characters, in the shape of Physicians, one in particular, Thomas Diafoirus ${ }^{104}$ sustained by M. Monrose, ${ }^{105}$ which seemed to give universal satisfaction, a most admirable caricature of our profession. The whole piece wound up with the ceremony of "capping" 106 as we term it in Edinburgh - together with a procession in honor of Moliére. The curtain was raised, the stage was found turned into a church, occupying the anterior part was seen the bust of Moliére - forms were ranged on each side, $\&$ in the back part were seen two elevated platforms, one raised above the other. The orchestra then struck up a slow march \& the procession commenced coming forward - it was headed by a number of boys in black, holding up in their hands, each a glyster syringe, carried the same as soldiers

\footnotetext{
${ }^{99}$ The ticket prices were higher than those for the Théâtre du Palais Royal such that the parterre seats cost 2 francs 20 sous compared with 1 franc 5 sous. (Galignani's new Paris guide, [p.711] additional inserted page facing p. 540.)

${ }^{100}$ Anne Françoise Boutet Monvel Mars (1779-1847) was at the time still the principal female performer at the theatre and she was much admired. She retired in 1841 .

${ }^{101}$ Célimène was the lover of Alceste, the principal male role in the play.

${ }^{102}$ Galignani too commented on the fine paintwork in the interior, following refurbishment in 1822 , and on the proscenium and the "curtain" to which the diarist refers. (New Paris guide, p. 542.)

${ }^{103}$ The diarist is exaggerating here because there are in Le malade imaginaire only a few references to "lavements" and "purgations" even though there are also a few boisterous "purgare" and a "purgande" in the chorus of the third entrée. Molière (Jean Baptiste Poquelin, 1622-73), Oeuvres complètes de Molière, 6 vols, Paris, 1825; Le misanthrope, vol. 3, pp. 348-440, and Le malade imaginaire, vol. 6, pp. 359-417.

${ }_{104}$ The physician was actually the father, referred to as "Monsieur Diafoirus", his son was named Thomas.

${ }^{105}$ There is a Monrose in the Almanach général of 1842, listed as an "artiste".

${ }^{106}$ Capping: the ceremony of conferring a degree in Scotland.
} 
carry a drawn sword. These boys formed two lines, one on each side of the stage, the corps dramatique, both men and women then walked forwards two by two, each wearing a scarlet gown trimmed with $/ 37 v$ / fur, \& carrying in their hands a crown of laurel - the latter they laid at the foot of the bust of Moliére. As any particular actor was recognised, he was welcomed with loud cheers. $M^{e}$. Mars was received with most enthusiastic cheering. As each deposited his crown of laurel, he took his seat on the side benches - two (the Doctor Elect \& another) took possession of the elevated platforms - the latter pronounced a speech on the duties of Physicians \&c. in the most horridly dog Latin, that can be imagined. Some questions were then asked of the candidate, which he answered in the same barbarous language $\&$ after forcing on the cap, the curtain dropped, $\&$ so ended the piece - quite a Burlesque on our Examination. I am quite satisfied, that the proper method of learning the French language is, after becoming acquainted with it to a certain extent, to attend the theatre regularly. Nothing will so soon or so well teach the pronunciation. In particular, I never heard the language spoken so purely, \& so distinctly as by $\mathbf{M}^{\mathrm{e}}$. Mars. I $\mathrm{c}^{\text {ld }}$. follow her much better than any of the others.

\section{Friday $16^{\text {th }}$.}

Went this morning to the Hotel Dieu. Sanson performed amputation of the leg in a man, for fracture immed ${ }^{\text {ly }}$. above the ankle, followed by infiltration of pus between the muscles, \& into the joint. Breschet had several very good cases - one of infiltration of urine ${ }^{107}-\mathrm{I}$ don't know, from what cause, but he made a very extensive \& deep incision into the scrotum, extending it a considerable distance between the testicles. He removed the catheter, ${ }^{108}$ which was in the bladder, \& endeavoured to introduce another but $c^{\text {ld }}$. not succeedhe passed it into an abscess - from $/ 38 \mathrm{r} /$ which a small quantity of pus of bad nature, mixed with sanies ${ }^{109}$ was expelled. In the woman's [sic] ward, was a case of very violent bruise of the leg, followed by sloughing of the integuments, \& formation of an abscess in the calf, which B. opened today - he was keeping up constant irrigation. ${ }^{110}$ The woman with comp ${ }^{d}$. fract $^{\mathrm{r}}$. almost well - he kept up constant irrigation for 55 days \& four different times, when he applied dry dressings, inflam ${ }^{n}$. came on. The heel has been very bad, a small slough formed there, but by an ingenious method of supporting it on tapes, ${ }^{111}$ this ulcer is nearly healed. At Sichel's we had some good cases - yesterday he performed the operation of removing a fungus from the conjunctiva, but by some misfortune, the knife slipped thro' the cornea $\&$ procidentia ${ }^{12}$ of the Iris occurred. Today a rare case appeared of staphyloma of the ciliary body, a most peculiar appearance the eye had. At Ribail's, we repeated several very good bandages.

\footnotetext{
${ }^{107}$ Infiltration of urine: this occurs when one of the canals, ureters or the urethra, associated with the kidneys or the bladder, is ruptured such that urine escapes into the associated tissues or into the abdominal cavity where peritonitis may follow. (Larousse médical, p. 1230.)

${ }^{108}$ Catheter: a long hollow tube introduced into the bladder to remove the urine when the person is unable to pass it. Catheters were made either of silver, or more cheaply, of the elastic gum. Those for males were longer than those for females and the metallic ones were curved. (Hooper, Lexicon, p. 337.)

${ }^{109}$ Sanies: thin, limpid and greenish discharge from an ulcer or, as in this case, an abscess. The term "sanies" can also refer to a thick and bloody kind of pus. (Hooper, Lexicon, p. 1088.)

${ }^{110}$ Irrigation: maintaining a stream of water over the wounded area.

${ }_{111} \mathrm{~A}$ method of suspending the limb so that no weight is put upon the damaged heel.

${ }^{112}$ Procidentia: prolapse.
} 
Saturday $17^{\text {th }}$.

Went down to Hospice Necker ${ }^{113}$ to see M. Civiale ${ }^{114}$ perform the operation of Lithotrity, ${ }^{115}$ but the pat ${ }^{\mathrm{t}}$. was ill \& consequently it was postponed. I very much admired C's method of introducing a catheter - I never saw anything done better - he showed us his method also of washing out the bladder by means of a catheter with a compartment or division extending thro' the middle. One of the sides was connected with a pipe coming from a cistern of water much higher, than the pelvis of the pat ${ }^{t}$. - the other connected with a pipe, which terminated over an empty bucket. A stream of cold water passed from the former thro' the former ${ }^{116} \&$ escaped thro' the latter - this is Civiale's treatment of Catarrh of the bladder $^{117} \&$ Paralysis - \& he says very successful. Went to Charriére's [sic $]^{118}$ today with a friend to buy catheters - exceedingly cheap - only $8 \mathrm{f}^{\mathrm{r}}$. a dozen of Elastic gum ${ }^{119} \&$ bougies $6 \& 4 \mathrm{f}^{\mathrm{r}}$. $/ 38 \mathrm{v} /$ catgut \& wax. In England, the lowest price of Elastic Gum Catheters is $3 / 6$ a piece. ${ }^{120}$ Went to the Louvre, this is the latest day, except Tuesday, it will be open. A confounded annoyance for I am now just beginning to find out beauties. Must go there again Tuesday. At Lemaire's almost nothing - spoke of cauterization of the tooth with a hot iron \& also with various solutions - then of stopping bleeding after extraction of the teeth, which he manages by filling the hole with lint $\&$ applying a piece of cork above this, maintained in its place by means of the other teeth. ${ }^{121} \mathrm{He}$ then said a few words but not much of cleaning teeth - nothing of any consequence - only one lecture more - by the bye he broke off the tooth of a rabbit today to shew us that it $w^{\text {ld }}$. sprout out again. This is the case with all rodentia.

Sunday $18^{\text {th }}$.

At La Pitié, nothing particular. Went to the R. de Bouloi. $\mathbf{M}^{\mathrm{r}}$ Newstead made a most happy simile, - as, says he, the oriental Husbandman plants his rice $\&$ then waters it, $\&$ when the blade springs up - he keeps it constantly covered with water, to prevent the sun from scorching it up - so ought we continually to watch \& nurture any slight tendency to repentance \&c. in our own hearts - lest the world sh ${ }^{d}$. annihilate it.

Monday $19^{\text {th }}$.

Went this morning to $S^{t}$. Louis, some very excellent cases particularly at the Consultation Gratuite - one, which I $c^{\text {ld }}$. not properly understand - a case of what Gibert called syphilitic

\footnotetext{
${ }^{113}$ The Necker hospital, a non-specialist institution for both men and women, was originally a convent. It was suppressed during the Revolution in 1799, when Madame Necker purchased the place and, with assistance from Louis XVI, founded a hospital called the Hospice de Saint-Sulpice. It later took the name of its founder. It is the hospital where Laënnec practised and followed up his research. (Ratier, Medical guide to Paris, pp. 103-4.)

114 Jean Civiale (1792-1867), a urologist, was qualified both as a physician and a surgeon.

${ }^{115}$ Lithotrity: the procedure for breaking, through the urethra, a stone in the bladder so that the pieces could escape with the urine. Civiale, as well as Baron Heurteloup, was considered to be very skilful at this operation. The instrument used for this procedure of crushing stones or calculi is a lithotrite. (Hooper, Lexicon, p. 786.)

${ }^{116}$ The diarist probably meant to write "bladder". Civiale's equipment is clearly a form of douche.

${ }^{117}$ Catarrh of the bladder is also called catarrhus vesicae and consists of a discharge of mucus from the bladder. It is ropy and like that which is discharged from the nose in the more familiar cases of catarrh.

${ }^{118}$ Charrière, near the École de Médecine, was a supplier of cutlery, tools, bandages and surgical equipment. (Almanach général, 1842, p. 391.)

${ }^{119}$ Catheters made of the elastic gum were preferable to those made of wax. (Hooper, Lexicon, pp. 262-3.)

${ }^{120}$ The price in Paris was therefore $6 \mathrm{~s}$. 8d. for twelve elastic gum catheters, compared with 3s. 6d. for a single one in England, seven times the French price.

${ }^{121}$ That is by clamping the teeth together.
} 


\section{9-20 January 1835}

roseola. ${ }^{122}$ The spots appeared to me too brown, not the rose red, which I believe, is the characteristic of /39r/ at least the pure roseola. At Sichel's some very excellent cases of cataract \& Keratitis - got a child today at Clamart, ${ }^{123}$ shall commence dissections tomorrow - deo volente.

Tuesday $20^{\text {th }}$.

Went to the Venereal Hospital this morning - there were some excellent cases under Ricord. I hope to learn a good deal from my attendance on his practice, during the time I spend in Paris. ${ }^{124}$ Syphilis is quite a new subject to me. I have never yet studied it. ${ }^{125}$ The first case which I saw, was one of stricture ${ }^{126}$ - the treatment pursued, was division with a cutting inst ${ }^{t}$. invented by Amussat. ${ }^{127}$ From the description, which I have seen, I sh ${ }^{d}$. conceive it a much less dangerous, \& consequently much superior inst ${ }^{\mathrm{t}}$. to that of $\mathrm{M}^{\mathrm{r}}$. Stafford. ${ }^{128}$ The case of Gonorrhoea treated by the application of Nitrate of Silver, is going on very well, there is an exceedingly little discharge. There was a case in the ward of B---- which has almost entirely disappeared under the employment of Tartar Emetic ointment ${ }^{129}$ - which has only been used since Thursday last. I saw a fine example this morning of true Hunterian Chancre, ${ }^{130}$ the hardened base, \& excavated edges. Ricord endeavoured to explain it, by supposing the

\footnotetext{
${ }^{122}$ Roseola: a rose-coloured rash without weals or papulae and not contagious. It occurred mostly with a variety of febrile complaints and did not require additional treatment. It is not clear here if the case is in fact associated with syphilis because, although St. Louis was a specialist skin hospital, it did treat some syphilitic patients as well.

${ }^{123}$ Clamart, officially named the Amphithéâtre des Hôpitaux and opened only in 1833, was the larger of the two establishments built to replace the several dissecting rooms formerly scattered throughout Paris and closed down as a public health hazard. Clamart, controlled by the hospitals, was situated near the Jardin des Plantes. The unclaimed dead from the hospitals were brought there each morning in carts known as "Clamart". (Warner, Against the spirit of system, pp. 95-6.)

${ }^{124}$ From other entries it is clear that the diarist shared the view of many Americans that Parisian surgeons were sometimes prepared to trade the lives of patients for surgical knowledge (Warner, Against the spirit of system, p. 260), but he never criticises Ricord, and is grateful for his experience in Ricord's clinic.

${ }^{125}$ The diarist comments more than once on the absence of syphilis from his Edinburgh medical course.

${ }^{126}$ Stricture: contracted state of a tube or duct, such as the oesophagus, intestines, urethra or vagina. Strictures can be organic, for example, due to a tumour, or spasmodic, due to muscular contraction.

${ }^{127}$ Jean Zuléma Amussat (1796-1856) was well known for his skill in lumbar colostomy by means of an incision across the border of the lumbar region. His probe was much used in lithotrity operations. (Faber medical dictionary, p. 33.)

${ }^{128}$ Richard Anthony Stafford (1801-1854) was a skilful London surgeon who had been apprenticed in Cirencester to the father of Sir William Lawrence. In London at St. Bartholomew's Hospital he was appointed house surgeon by John Abernethy for 1823-24 and was admitted to the Royal College of Surgeons in 1824 before spending a year in Paris. In his book, A series of observations on strictures of the urethra (1828), he explained that he had "invented two instruments", one of which was to divide permanent strictures, which would still allow a small bougie or wire to pass, the other was "to divide those strictures which are impermeable". The former instrument, made of silver, was called the double lancetted stilette, whilst the latter was similar but had a single lancet. Stafford explained how they should be used and provided illustrations (pp. 70-6, 157-9, figs. 1-9).

${ }^{129}$ Tartar Emetic ointment: Milne-Edwards and Vavasseur indicate that such an ointment or pomade should be rubbed in two or three times a day. (Nouveau formulaire, p. 346.)

${ }^{130}$ Chancres: these are the sores which arise in venereal infection and they appear mainly on the genitals. John Hunter (1728-93) and John Abernethy (1764-1831) described as syphiloid those diseases which have a close resemblance to venereal disease including the pseudo-syphilis or bastard pox. The distinction between syphiloid affections and genuine syphilis was frequently difficult but of importance since treatment with mercury was seldom successful and could be harmful. See also November 3, note 37, and November 10, note 110. (See John Hunter, A treatise on the venereal disease, 1818; John Abernethy, Surgical observations on diseases resembling syphilis, 1810; Hooper, Lexicon, p. 1190.).
} 


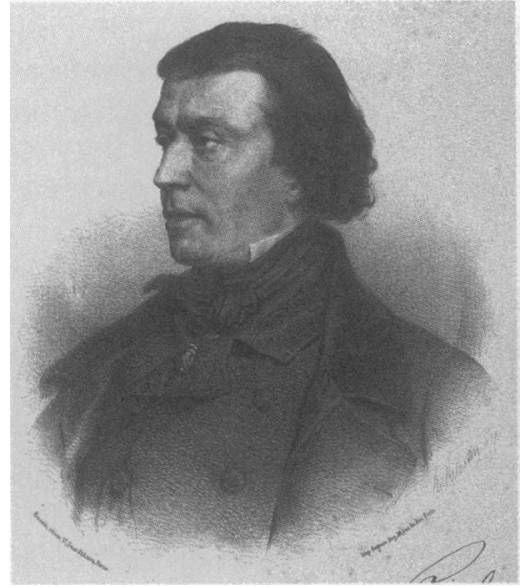

Figure 17: Philippe Ricord (1800-89). Lithograph by L. Valentin. (Wellcome Library, London.)

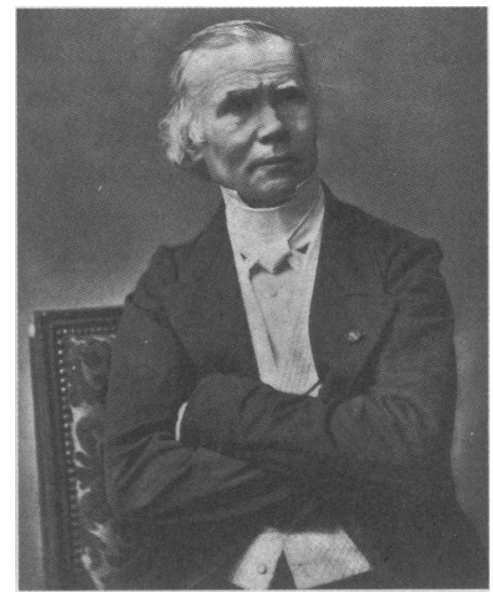

Figure 18: Alfred Armand Louis Marie Velpeau (1795-1867). Photograph by Pierre Petit. (Wellcome Library, London.)

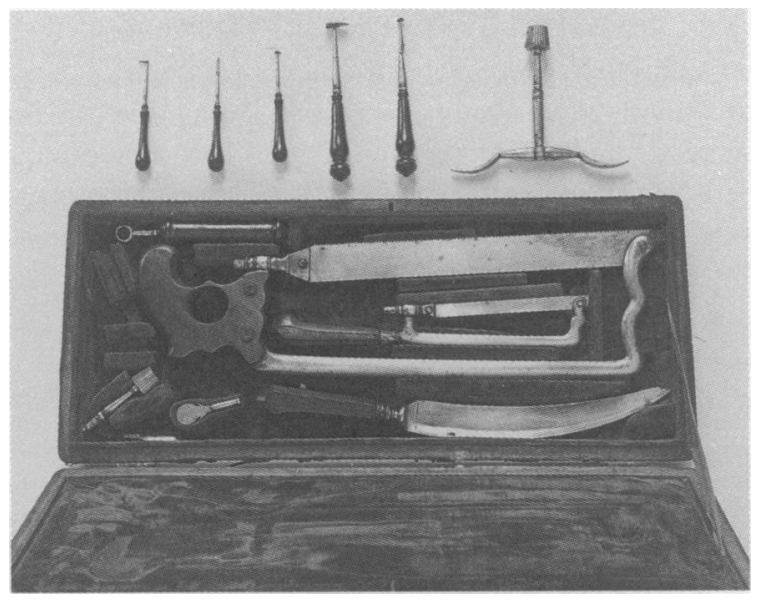

Figure 19: An eighteenth-century case containing the instruments necessary for amputations. (Photo, Wellcome Library, London.)

formation of a kind of abscess, which bursting left a portion of its parietes, \& certainly when the excavated borders were raised upon the probe - they had just the appearance which $w^{\text {ld }}$. have been presented by the walls of an abscess. I saw today a most extraordinary kind of Chancre, exceedingly deep - it was situated on the superior surface of the glans - the base was covered with a thick yellow slough - its borders were not very determinate, \& M. Ricord considered, that the destructive process was not at an end. There is great danger of its extending even into the urethra - the local treatment adopted in all these cases was the application of Nitrate of Silver in substance - to the latter case was also applied a strong 
solution of opium. The person with the Hunterian Chancre was taking Mercury - the Protoiodide was the form employed. With respect to this medicine, Mercury, M. Ricord laid it down as a maxim, that when the base was hardened, with much effusion of lymph into the cellular tissue, it was almost invariably proper - he did not consider it in the light of a specific $^{131} / 39 \mathrm{v} /$ but, as producing absorption of the lymph, \& thereby a tendency to cicatrisation. ${ }^{132}$ When on the contrary the ulcer is phagedaenic, ${ }^{133}$ mercury is almost invariably injurious, for by its tendency to increase absorption, it must assist in extending the ulceration. To almost every case of chancre, $\&$ in every stage he applied the Nitrate of Silver - without the previous administration of mercury - which is consid ${ }^{\mathbf{d}}$. indispensible by many practitioners in England. There was one fine example of Syphilitic Eruption of a papular ${ }^{134}$ form - which M. R. seemed to consider merely the commencement of syphilitic crusts. M. R. performed the operation of circumcision ${ }^{135}$ more dexterously, than I $c^{\text {ld }}$. have conceived possible - he first marked out with ink, what was necessary to be removed - he then drew the foreskin as forward as possible, grasped it by a pair of forceps \& with one rapid cut, sliced off all the skin above them - he then allowed it to be retracted - the gland still remained covered with the mucous membrane - this he divided \& removed, making altogether a beautiful \& not particularly painful operation. In several cases of nodes ${ }^{136}$ M. R. has employed very successfully the local application of a strong solution of Iodine from $3 i$ to 3 iii to $\xi_{i}$ of the solvent. I have since been informed by a friend, who has studied in the London Hospitals, that he has seen the remedy had recourse to there, with advantage $\&$ even the internal administration of Hydriodate of Potass ${ }^{137}$ has appeared useful. Dissected a little at Clamart, \& then went to my bandaging - applied the spica ${ }^{138}$ of the groin \& one or two more. At Sichel's scarcely any cases - so I went off to the Louvre. Today the Museum closes 'till March. Went to Lemaire's - this was the last lecture. He showed us how to fasten in a tooth, which was loose, by means of silk, catgut or wire - then to fasten in a single tooth, when the root of the other remains, by boring a hole in the latter \& fixing a wire coming from the artificial tooth into it. /40r/ He shewed us how to take the impression of the teeth in sealing wax by making the latter by heat sufficiently soft - moulding it on the part \& covering it with softened Sulphate of Lime ${ }^{139}$ - the latter is easily taken off by heating it slightly, after it has set, $\&$ we have left a complete mould of the teeth. ${ }^{140}$

\footnotetext{
${ }^{131}$ A specific was a remedy considered to have an infallible efficacy in the cure of disorders. (Hooper, Lexicon, p. 1144.)

${ }_{132}$ Cicatrisation: healing over of a wound which may lead to the formation of a scar.

${ }_{133}$ Phagedaenic: ulceration which spreads very rapidly.

${ }^{134}$ Papular: small nodular elevations of the skin.

${ }^{135}$ There was a sizeable Jewish community in Paris who would have carried out this procedure as a religious ceremony. Circumcision was also used in the treatment of syphilis.

${ }^{136}$ Nodes: hard circumscribed tumours caused by swelling of the periosteum surrounding the bone. Nodes can appear in any part of the body but are more common on bones that are thinly covered with muscle such as the front of the leg bones. (Hooper, Lexicon, p. 884.)

${ }^{137}$ Hydriodate of Potass.: this potassium-containing substance had the same properties as iodine but was weaker in its action as a therapy for conditions of goitre, certain swellings and some cancers. (Milne-Edwards and Vavasseur, Nouveau formulaire, p. 265.)

${ }^{138}$ Spica: in surgery a form of bandaging whose turns resemble the ears of corn on the stem.

${ }^{139}$ Sulphate of lime is the main constituent of gypsum, which was widely used in orthodentistry as well as in plaster of Paris. See note 141.

${ }^{140}$ Galignani lists two dentists recommended for English speakers in Paris: Désirabode, described as a surgeon and dentist of the Faculty of Paris whose "artificial teeth are remarkable for their solidity and
} 


\section{0-21 January 1835}

Irregularity in the teeth is cured in this way - if the under teeth project forward in front of the upper - a small layer of gold or some other metal must be obtained, which fits the neighbouring teeth \& is fastened around the most posterior on each side. Opposite the rest of the irregular teeth there is a hinge joint, \& the piece of metal ascends in this manner $f$ the straight portion passing in front of the teeth, \& the bent or upper portion, or inclined plane-comes on the top-so that the teeth of the upper jaw resting on this latter have a constant tendency to force the lower ones inwards. The same treatment must be employed for the forcing of the upper teeth outwards. This treatment $w^{\text {ld }}$. have a tendency to bring them forwards. When the deformity is not great, it may be remedied by applying a piece of metal on the molars, thus preventing the front teeth from ever coming together. Nature alone will then produce the cure. Opposite the irregular teeth, there $\operatorname{sh}^{d}$. be two holes bored, to enable us to fix the inst ${ }^{t}$. by means of silk. This inst ${ }^{t}$. is easily made by sending the cast of the jaw in Plaister of Paris ${ }^{141}$ to any working jeweller - the cure requires 15 days. Velpeau's case is dead - a downright murder for which he ought to be prosecuted ${ }^{142}$ - In V.'s ward today - there was I understand, a person whose bowels had not been opened for a month. Velpeau had forgotten to ask this necessary question, yet the pat ${ }^{t}$. was labouring under head affection. Is it any wonder!

\section{Wednesday $21^{s t}$.}

Went this morning to the St. Louis - first followed M. Biett round two of his wards - some very good cases new \& old then went round with Lugol. Scrophula is a most extraordinary disease. I had no idea of the numerous forms it assumes - the practice is very successful of combining the $/ 40 \mathrm{v} /$ external $\&$ internal administration of Iodine with constant exercise. ${ }^{143}$ M. Lugol said, that he considered it necessary to keep up the action of Mercury at least a month after the symptoms in syphilis have entirely disappeared - or they will almost infallibly return. They seem not to be much afraid of the action of mercury in syphilis combined with scrophula in this Hosp 1 . - but in such cases they prefer the Ioduret ${ }^{144}$ of

brilliancy", and Vleminex, described as a manufacturer of mineral teeth. A special recommendation in his favour was that "Persons who do him the honour of calling on him are not exposed to meeting each other" (New Paris guide, p. lxxiv).

${ }^{141}$ Plaister of Paris: i.e. plaster of Paris. It is made by rendering gypsum anhydrous through calcination, that is rendering it to a powdery substance, through heating at a high temperature. The resulting substance swells and rapidly sets when mixed with water hence its use in making moulds and casts. It is so named because it is prepared from the gypsum of Montmartre, then a village outside Paris. (Nysten, Dictionnaire de médecine, 9th ed., p. 1101; Galignani's new Paris guide, p. 656.)

${ }^{142}$ Warner speaks of harsh American criticism of French medicine at that time. It was seen as highly scientific and good at diagnosis but inadequate therapeutically. In fact some Paris surgeons were believed to place little value on suffering or preserving life. They were sometimes denounced as particularly brutal, rendering the great hospitals "little better than charnel houses and butcher shops". (Against the spirit of system, pp. 257-8.)

${ }^{143}$ Milne-Edwards and Vavasseur include scrophula along with goitre and other conditions as amenable to treatment both externally with a tincture of iodine three times a day and internally with pills twice a day, and provide prescriptions for both. Since in high doses iodine is a poison there is the warning that it should be used with great restraint. (Nouveau formulaire, p. 265.) Iodine was widely used in the treatment of scrophula, but was not generally found to be more efficacious than soda and, like conium (hemlock), could affect the head with its inebriating qualities. According to Hooper, Matthieu Orfila (who specialised in chemistry and carried out experiments on animals and on himself) swallowed 6 grains of iodide and was immediately affected with heat, constriction of the throat, nausea and other unpleasant symptoms. (Lexicon, p. 735.)

${ }^{144}$ Milne-Edwards and Vavasseur provide two prescriptions for ioduret substances, one of which was attributed to Lugol himself - both containing potassium but not mercury - associated with the St. Louis. One was listed as used by Lugol in the treatment of scrophula. (Nouveau formulaire, pp. 265-6.) 


\section{1-22 January 1835}

Mercury to produce mercurialism. ${ }^{145}$ At Alibert's Clinique there were a few good cases but not many - one of Purpura Haemorrhagica. ${ }^{146}$ The solution of Iodine which he uses for outward application is $\mathbf{R}$ Iodine $\xi_{i}$ Iod: Potass: $\xi_{\text {iii Aq: }}$ pura $\xi_{\text {iii }} \mathbf{M} \mathbf{f}^{\mathbf{t}}$. Solutio-M. Ricord's was thrice as strong - using the same quantity of Iodine, but only $\xi i$ of water. At Ribail's we went over some of M. Maynor's [sic] Bandages. ${ }^{147}$ At Sichel's, we had a capital case of dropsy of the eye with protrusion of the choroid membrane $\&$ corps ciliaire. ${ }^{148}$ The appearance of the eye was very extraordinary - projecting very much forward, \& on the outer side, almost square - the eyelids $\mathrm{c}^{\text {ld }}$. be scarcely closed. Today I paid Madame Lecomte for my second month['s] lodging, \& boarding, postage, \& candles $69 / 50^{149}$ - the month terminated yesterday.

\section{Thursday $22^{\text {nd }}$.}

Went to Louis' Clinical Lecture. Velpeau examined today the head \& neck of the man he killed the other day - there was so great a crowd around, that I $\mathrm{c}^{\text {ld }}$. not see anything ${ }^{150}$ - but I heard a rumour that it was uncertain, whether the disease were or were not aneurism. I suppose, he will lecture on the case tomorrow /41r/morning. Called on Bird - he told me that he met the two Jekyl's[?] ${ }^{151}$ in the R. de la Paix. I think I saw them in the Louvre on Tuesday last. At Ribail's, we were shown some very good bandages for the extremities. At Sichel's, some capital cases, particularly of Catarract - the different kinds, \& Amaurosis there is considerable difficulty in distinguishing between these different diseases in many cases. There was a person at the Clinique today, with an appearance in his eyes, which all the students considered Cataract - but which Sichel declared to be Amaurosis.

\footnotetext{
${ }^{145}$ Mercurialism: the symptoms of this, including excess flow of saliva - ptyalism - and violent purging, can be dangerous if too extreme, and may accompany the use of mercury in conditions such as syphilis. Hooper warns that it could be dangerous to submit the patient to hasty withdrawal of mercury in cases of excessive ptyalism. (Lexicon, p. 835.)

${ }^{146}$ Purpura haemorrhagica: one of the more severe forms of purpura in which the petechiae or red/purple spots resembling flea bites were larger and interspersed with bruise-like patches. Bleeding could occur, especially from the gums, tongue, nose and throat, and the patient experienced great fatigue. The causes of this disease were not known. It could affect both sexes at any period of life. Iron preparations were prescribed. (Hooper, Lexicon, pp. 1034-35.)

${ }^{147} \mathrm{He}$ could have meant Mathias Louis Mayor's (1775-1847) bandages and have been misled by the pronunciation. Mayor's bandages were formed from a basic piece of triangular cloth which was then folded and used on different parts of the body as appropriate. In Larousse médical, which provides illustrations, they are described as "the simplest and most practical of bandages" (p. 132).

${ }_{148}^{148}$ Corps ciliaire: French for the ciliary body of the eye.

${ }^{149} 69$ francs, 50 sous, just under $£ 25 \mathrm{~s}$.

${ }^{150}$ Warner refers to the large numbers of students crowding around cadavers in the dissecting room and provides references to work which expressed concerns about the potentially brutalising effects on them of the experience. He also provides an illustration from an 1840s novel of a Paris medical student who carved his initials on the arm of a dead actress, claiming her as his own for the dissecting table. (Against the spirit of system, pp. 262-5.)

${ }^{151}$ The "two Jekyl's", who do not appear in the contemporary student lists for Edinburgh, could have been the two sons of Joseph Jekyll (d. 1837), a wit and politician who, through influential support, had been a Whig member of parliament for Calne in Wiltshire and had practised as a lawyer on the western circuit, in the diarist's home region. Jekyll, who was considered to lack "serious knowledge" wrote wittily about Pitt's salt-tax but had himself been caricatured by James Gillray (1757-1815). Perhaps the diarist felt some affinity with the two Jekylls in Paris, because, like him, they hailed from the south-west of England.
} 
Friday $23^{\text {rd }}$.

Went down to Sanson's this morning - there was a very interesting case - Gangrene of the toes produced by Popliteal Aneurism. ${ }^{152} \mathrm{M}$. S. acknowledged he did not know what to doif he operated, the gangrene $w^{\text {ld }}$. certainly extend - if he did not - the gangrene $w^{\text {ld }}$. not, he tho $^{t}$., be cured. There was a case of amputation of the leg - or rather a case in which amputation had been performed - apparently about 10 days ago. M. S. appeared exceedingly anxious to prevent union by the first intention. He had not only introduced a large $q^{\text {tty }}$. of charpie between the edges of the wound, but fearing, lest there may be some stray bands of lymph, he passed his finger all round to rupture them, if any $s^{d}{ }^{d}$. exist. Went into Breschet's ward. He had a case, the very opposite of that of Sanson's. He had dressed a stump à l'Anglaise, ${ }^{153} \&$ had procured almost complete union by the first intention. Saw two or three cases of Erysipelas treated with the constant application of cold water, particularly one of Erysip. faciei - according to the opinion of most English Pathologists this is a dangerous practice $^{154}$ - but I question whether this opinion be well founded. Lawrence recommends warm or cold applications, according to the feelings of the patients. ${ }^{155}$ Velpeau the other day had a case of Erysip. Phlegmon. ${ }^{156}$ of the thigh under his care - the first day he applied a blister to the part, the second, he cauterized it several times with a hot iron ${ }^{157}$ - the third day, he made several incisions thro' the integuments. Consid' ${ }^{1}$. flow of pus took place $\&$ the man was amazingly relieved - but being old \& worn out with /41v/ irritation, he died this morning. Now I sh ${ }^{d}$.very much like to know, why in the name of common sense, he trifled with the life of the man in this way. ${ }^{158}$ It is very probable, that the pat ${ }^{\mathrm{t}}$. $\mathrm{w}^{\text {ld }}$. have died at all events, but this practice destroyed the only remaining chance, the man had. Neglecting for three days to make incisions in Phlegmon. Erysip. is sufficient of itself, without the additional irritation produced by a blister $\&$ actual cautery, ${ }^{159}$ to cut short the life of even a young healthy man. At the consultation of $\mathrm{M}$. Breschet there was a fine example of

\footnotetext{
${ }^{152}$ Popliteal aneurism: the popliteal region is that behind the knee and aneurisms may occur in the popliteal artery.

${ }^{153}$ Dressing a stump à l'anglaise involved using a circular bandage which acted by supporting the skin and muscles. It was intended to prevent their retraction, which led to an unattractive mushroom shaped stump. Since this dressing did not always succeed, Samuel Sharp (1700?-78) used the cross bandage over the end of the stump. (Cooper, Dictionary of practical surgery, p. 66.) Sharp, a Jamaica-born surgeon, was apprenticed to William Cheselden at St Thomas's Hospital. He became a surgeon at Guy's Hospital in 1733. See his $A$ critical enquiry into the present state of surgery, 1750.

${ }^{154}$ Hooper certainly agreed that cooling the part with cold water was the best application to use but he advocated that this should be done "occasionally". (Lexicon, p. 555.)

${ }^{155}$ Hooper was against using astringents too freely on the head and face, but recommended, where there was much pain and heat, that "cooling it" occasionally with plain water was perhaps the best. (Lexicon, p. 555.)

${ }^{156}$ Erysip. Phlegmon.: i.e. erysipelas phlegmonodes. This form of erysipelas - in which the redness of the skin was brighter than in the other forms - occurred most frequently on the face, usually affecting one side only. Sometimes, as in this case, it attacked one of the extremities. Gangrene was a danger of the condition. Cupping (behind the neck in cases where the face was affected), cooling saline purgatives and a light vegetable diet to sustain the patient's strength were recommended. (Hooper, Lexicon, p. 553.)

${ }^{157}$ This cauterization was intended to prevent gangrene setting in.

${ }^{158}$ This comment on Velpeau, together with that of January 20 , indicates that the diarist shared the view of many foreigners that Parisian surgeons were not averse to trading the lives of their patients for surgical knowledge. Indeed, one American student writing home to his parents declared, "human life, is not esteemed of much value in the hospitals of Paris - an experiment is worth a dozen lives". (Warner, Against the spirit of system, p. 260.)

${ }^{159}$ Actual cautery: see February 16, note 32.
} 


\section{3-25 January 1835}

malignant cancerous sore at the side of the cheek - with hardened, ragged edges \& malignant looking centre - it had existed for two years. At Sichel's there were several fine cases particularly one of cataract ${ }^{160}$ in the right eye, there was central capsular - \& in the left a most extraordinary kind, radiated, commencing from the circumference. However S. consid $^{\mathrm{d}}$. it was lenticular. Began dissecting today in a foetus, had very tolerable view of the brain, \& exit of the nerves from the cranium, indeed I never saw the spinal accessory ${ }^{161}$ so plainly before, ascending into the cranium \& emerging thro' the foramen lacerum posterius. ${ }^{162}$ Afterwards dissected the orbit.

Saturday $24^{\text {th }}$.

Went to La Pitié - followed Velpeau - nothing particular there. In the dead House the poor Erysipelatous pat ${ }^{t}$. of Velpeau. V. did not come down himself - but sent one of his externes to examine the body, \& a more slovenly dissection it was never my misfortune to witness. The cranium was opened - the brain cut away in pieces 2 inches at least thick. No particular examination of the ventricles, some fluid escaped which was presumed to come from these cavities - no collection of this to ascertain whether the quantity were preternatural or otherwise. It is true, there were no signs of affection of the head during life \& the externe might consider this a justification /42r/ of his superficial examination - but why in that case open the head at all $\&$ destroy the brain - it $c^{\text {ld }}$. do the dissector no good, anatomically speaking, $\&$ it is nonsense to pretend that he $c^{\text {ld }}$. discover any disease which might have existed, by such an exceedingly superficial examination. Chest was not opened. Abdomen was opened \& of course the muscles destroyed for the dissection, but none of the viscera examined - surely one $w^{\text {ld }}$. have imagined that in Paris where Broussais' ideas have made so many converts, they $\mathrm{w}^{\text {ld }}$. take every opportunity of seeing whether they really are founded on fact - but here was a chance of ascertaining the truth of one of his most improbable opinions, \& it was allowed to pass by unregarded. ${ }^{163}$ I was dreadfully annoyed to see such a sacrifice first of so valuable an autopsy, $\& 2^{\text {ly }}$. of so valuable a body for dissection. The externe then dissected off the integ ${ }^{\text {ts }}$. of the whole of the front of the leg. Opened about an inch of the upper part of saphena vein - \& then left the room quite satisfied, I presume, with having done all the injury he possibly $\mathrm{c}^{\text {ld }}$., \& with having put it out of the power of everyone else to profit by the opportunity, more than himself. At Ribail's some common bandages for the hand $\&$ arm. Dissected the Pectorales, $\&$ the abdom ${ }^{1}$. muscles - the reflections ${ }^{164}$ of the periton $^{\mathrm{m}} . \&$ the liver in the foetus.

Sunday $25^{\text {th }}$.

Went to Louis' ward - nothing particular, his usual vast proportion of "Tubercles"165 _ went to R. de Bouloi.

\footnotetext{
${ }^{160}$ The diarist has trouble with the spelling of this word, which he corrects in situ by overwriting, as with others such as catarrh.

${ }^{161}$ Spinal accessory: this is the eleventh cranial nerve.

${ }^{162}$ Foramen lacerum posterius: an opening at the base of the skull.

${ }^{163}$ On Broussais's ideas, see November 7, note 82, and February 23, notes 57 and 58.

${ }^{164}$ Reflection: the process of folding back the anatomical parts during the dissection.

${ }^{165}$ At this time, Louis was pre-eminently concerned with his research on tuberculosis and the identification of tubercles as a sound diagnostic feature. He also applied numerical and statistical methods to his research,
} 
Monday $26^{[t h]}$.

Went to $\mathbf{S}^{\mathbf{t}}$. Louis, saw some very good cases - particularly of Pityriasis Versicolor, of Impetigo of the scalp, Herpes Circinatus \& Zoster there was also a case of old Variola - the true pustules had disappeared but it had left in the face papules, rather large perhaps, but otherwise very similar to those of Lichen - in other parts of the body the varioloid ${ }^{166}$ appearance was better marked. A case of syphilitic psora also. At Sichel's some good cases. I understand that Velpeau has discovered that the case in which he tied the carotid was /42v/ not aneurism, but Encephaloid disease ${ }^{167}$ - this is still a great reason why the case $\operatorname{sh}^{\mathrm{d}}$. be published - it was sheer murder \& does not deserve a milder name.

Tuesday $27^{[t h]}$.

Went to the Venereal Hosp' ${ }^{1}$ - but Ricord having finished his visit to the men - ret ${ }^{\mathrm{d}}$. to La Pitié \& went round with Velpeau. He has an extraordinary case of tumor, situated below the ribs of the right side - it came on suddenly after a fall - he had no pain of any kind. The tumor is soft \& appears to contain fluid. Nothing can either be heard or felt there - Velpeau does not know what to do. Sichel performed the operations today of depressing a cataract \& opening the Sac Lachrymose. ${ }^{168}$ Dissected part of the abdomen \& chest tonight.

Wednesday $28^{\text {th }}$.

Went to $S^{\mathbf{t}}$. Louis this morning - followed M. Lugol. He appears to entertain an opinion that in many cases scrophula is the consequence of hereditary syphilis. ${ }^{169}$ Phthysis, he said, was to be treated by good diet \&c so as to strengthen the system as much as possible - bleeding \& other evacuants injurious. I suspect in this, he is not far wrong - but I question much, if such an opinion were to get abroad whether it $\mathrm{w}^{\text {ld }}$. not do more harm than good. Bronchitis \& many inflammations $w^{\text {ld }}$. by many be treated in this manner (Mem: the quinine treatment of $\mathbf{M}^{\mathrm{r}}$. Mortimer) - Vide the art: on Phthysis in the Cyclop: of Pract: Med: by Cheyne. ${ }^{170}$ The tumors found in the neck of scrophulous subjects $M$. L. stated to be new formations, not indeed lymphatic glands, as is generally believed, but true bona fide tubercles. Tubercles in the lungs, he does not consider exactly analogous, nor does he consider they essentially are

and this approach gained the name "numerical method". Louis spent an enormous amount of time analysing his data. This could have contributed to the view among some of the English-speaking students that he was more interested in making his diagnoses than in the treatment required to help the patients.

${ }^{166}$ Varioloid: mild form of variola or smallpox seen in persons who had attained a degree of immunity through vaccination with smallpox virus.

${ }^{167}$ Encephaloid disease: a soft form of cancer (sarcoma) as opposed to the hard form (scirrhus). The term was used by Laënnec because these soft forms of cancer frequently resembled the medullary substance of the brain. (Larousse médical, p. 500.)

${ }^{168}$ Sac Lachrymose: lachrymal sac. This is a membranous sac linked to the lachrymal ducts above and, via the nasal duct, the nasal cavity below. It is part of the drainage pathway for the eye.

${ }^{169}$ Hereditary syphilis: this was also known as congenital syphilis on which later in the century Jonathan Hutchinson (1828-1913) of Selby, Yorkshire, worked extensively. He noted the early symptoms of the first few months of life. He also drew attention to the state of the teeth, especially the permanent set, as providing one of the most valuable diagnostic criteria of hereditary syphilis. (Crissey and Parish, Dermatology and syphilology, pp. 224-30.)

${ }^{170}$ John Cheyne (1777-1836) in his article on 'Epidemic gastric fever' included phthysis as a complication of that condition. (Cyclopaedia of practical medicine, vol. 2, pp. 215-20.) 


\section{8-31 January 1835}

formed in scrophulous subjects. ${ }^{171}$ The solution of Iodine, ${ }^{172}$ which he uses, is nearly the same as that employed by $M$. Alibert, but rather stronger $-/ 43 r /$ in scrophulous diseases of the joints he does not consider rest essentially necessary. At M. Sichel's today, he stated, that the instillation of Belladonna was one of the best preservatives against iritis after all operations on the eye.

\section{Thursday $29^{\text {th }}$.}

Went to Louis' lecture at La Pitié - dissected for two hours. Went to Sichel's, nothing particular - engaged this Evening to take tea with $\mathbf{M}^{\mathrm{r}}$ Newstead's family - quite delighted with the appearance of cheerfulness \& happiness, which every person manifested. What a contradiction to those who say that religion has a tendency to make a person gloomy, \& cause him to give up all the pleasures which render life tolerable. There was singing of sacred music, reading of a chapter in the Bible, $\&$ afterwards playing ${ }^{173}$ - somewhat different but much more rational, than many parties, at which I have been present.

Friday $30^{\text {th }}$.

Went round with Beschet at the Hotel Dieu - no cases of any importance - went to the Banque de France to change a note of F500. ${ }^{174}$ At Sichel's several good cases. Must write some letters tonight.

\section{Saturday $31^{\text {st }}$.}

Sat up last night or rather this morning till $1 / 2$ past 3 A.M. writing letters - conseq ${ }^{\text {ly }}$. was not up in time to go to the Hosp. ${ }^{1}$ - took a turn in the Jardin du Roi ${ }^{175}$ - afterwards remained in all day reading \& writing. $\mathrm{M}^{\mathrm{r}} \mathrm{King}^{176}$ went to England today, he carried three letters for me to Clifton, Wincanton \& Franklyn. ${ }^{177}$

\footnotetext{
${ }^{171}$ According to Hooper, who appears to disagree with Lugol, when the bodies of scrophulous subjects were opened many of the viscera were in a diseased state, including the lungs, which could be beset with a number of tubercles or cysts. (Lexicon, p. 1106.)

${ }^{172}$ For iodine, see this month, note 143.

${ }^{173}$ The second letter of this word has been over-written so that it is not clear if he meant "playing" or "praying". He gives no idea of any games which might have been played and the programme for the evening seems to have been somewhat austere for a party.

${ }^{174}$ The only notes issued by the Bank of France at the time were of 500 francs and 1,000 francs. They were exchangeable into silver at the Bank during business hours without discount except for a 3 sous charge for the bag which contained the coins. Alternatively, for a small premium, the notes could be changed into silver or gold at a moneychanger establishment. The 500 franc note was equivalent to $£ 2016 \mathrm{~s}$. 8d. at the time.

(Galignani's new Paris guide, p. iii.)

${ }_{175}$ Jardin du Roi: he probably meant the Jardin des Plantes founded in 1626, but which did not open until 1635. It was located beside the Natural History Museum (see March 4, note 8).

${ }^{176}$ There is an Abraham King who had gained the MRCS and LSA qualifications in 1834 and who was later a Medical Officer to the Union Workhouse in Bridgewater, Somerset, not too far from the diarist's home area (London and Provincial Medical Directory, 1849, p. 357.)

${ }^{177}$ There was a regular postal service between Paris and London. The post for England, for which letters had to be received by the Post Office by 3 o'clock, was on Mondays, Tuesdays, Fridays and Saturdays. Letters arrived from England on Sundays, Mondays, Thursdays and Fridays. The cost of sending an ordinary sized letter for England was 16 sous and for a letter from England 24 sous depending on weight. There was a quicker but more expensive service via Calais which had been established only in 1829. (Galignani's new Paris guide, pp. 243-7.)
} 